\title{
Linear and branched alkyl-esters and amides of gallic acid and other (mono-, di- and tri-) hydroxy benzoyl derivatives as promising anti-HCV inhibitors
}

Eva Rivero-Buceta, ${ }^{a}$ Paula Carrero, ${ }^{b}$ Elisa G. Doyagüez, ${ }^{c}$ Ernesto Quesada, ${ }^{a}$ María José Camarasa, ${ }^{a}$ María Jesús Peréz-Pérez, ${ }^{\mathrm{a}}$ Pieter Leyssen, ${ }^{\mathrm{d}} \mathrm{Jan}$ Paeshuyse, ${ }^{\mathrm{d}} \mathrm{Jan}$ Balzarini, ${ }^{\mathrm{d}} \mathrm{Johan}$ Neyts ${ }^{\mathrm{d}}$ and Ana San-Félix*a

\author{
"Instituto de Química Médica (IQM-CSIC), Juan de la Cierva 3, 28006 Madrid; Fax: 3491 5644853; Tel: 34912587617 \\ b 'Presentadress': ABG Patentes, Avenida de Burgos 16D, 28036 Madrid; Tel: 34914171300 \\ c 'Present adress': Centro de Química Orgánica “Lora-Tamayo” (CSIC), Juan de la Cierva 3, 28006 Madrid; Fax: 34915644853 ; Tel: 34 91 \\ 5622900 \\ ${ }^{d}$ Rega Institute for Medical Research, KU Leuven, B-3000 Leuven, Belgium; Fax: 32 16 337340; Tel: 3216337341
}

\begin{abstract}
On the basis of the antiviral properties exhibited by the natural green tea catechins that contain galloyl groups, we here describe the synthesis of novel synthetic analogues that contain in a single molecule two, three or five units of galloyl (3,4,5-trihydroxybenzoyl) or its isomer 2,3,4-trihydroxybenzoyl, as well as other mono- or dihydroxybenzoyl moieties. These molecules have been evaluated for their in vitro inhibitory effects against a wide panel of viruses showing preferential activity against HIV and HCV.

Our structure-activity relationship studies demonstrated that the 2,3,4-trihydroxybenzoyl moiety provides better antiviral activities than the galloyl (3,4,5-trihydroxybenzoyl) moiety that is present in natural green tea catechins. This observation can be of interest for the further rational exploration of compounds with anti-HCV/HIV properties.

The most notable finding with respect to HIV is that the tripodal compounds $\mathbf{4 3}$ and $\mathbf{4 5}$, with three 2,3,4trihydroxybenzoyl moieties, showed higher activities than linear compounds with only one or two. With respect to HCV, the linear compounds, $\mathbf{5 2}$ and $\mathbf{4 1}$, containing a 12 polymethylene chain and two 2,3 di- or 2,3,4 tri-hydroxybenzoyl groups respectively at the ends of the molecule showed good antiviral efficiency. Furthermore, the anti-HCV activity of both compounds was observed at concentrations well below the cytotoxicity threshold. A representative member of these compounds, 41, showed that the anti-HCV activity was largely independent of the genetic make-up of the HCV subgenomic replicon and cell lines used.
\end{abstract}

Keywords: Antiviral agents, AIDS, HIV, HCV, polyphenols

Corresponding author:

Instituto de Química Médica (CSIC), Juan de la Cierva 3, 28006 Madrid

Telephone: 3491 2587617; Fax: 34915644853

E-mail: anarosa@iqm.csic.es

\section{Introduction}

Several chronic viral infections (such as AIDS and hepatitis C) are highly prevalent and a serious health risk for which there is no curative treatment and no vaccine.

Hepatitis $\mathrm{C}$ virus (HCV) belongs to the family of Flaviviridae and is an important aetiological agent causing chronic hepatitis that can progress further to hepatocellular carcinoma [1]. A "dual therapy" based in the combination of pegylated interferon-alpha (PEG-IFN $\alpha$ ) and ribavirin was the standard therapy of chronic HCV infection for more than 10 years [2]. 
In recent years the advances in the knowledge of the hepatitis $\mathrm{C}$ life cycle resulted in the development of different classes of direct-acting antiviral (DAA) agents [3]. These drugs act as inhibitors of different non-structural HCV proteins such as: NS3/4A protease, NS5BRNA-dependent RNA polymerase and NS5A. In 2011, the first two DDAAs, telaprevir and boceprevir, targeting the NS3/4A protease of HCV, have been approved by the FDA for chronic HCV infection [4]. These drugs, used in combination with peginterferon and ribavirin as a "triple therapy", have significantly increased the sustained viral response rate for patients infected with genotype 1 viruses $(\sim 75 \%$ versus $\sim 45 \%$, in the "dual" combination therapy). Despite this major therapeutic success the "triple therapy" is associated with numerous side effects and is limited to genotype 1 viruses [5]. These limitations highlighted the urgent need for new lead compounds and novel therapeutic concepts to fight against Hepatitis $\mathrm{C}$ infection.

With respect to infection with Human Immunodeficiency virus (HIV), the introduction of highly active antiretroviral therapy (HAART), in the late 1990s, have significantly contribute to reduce the morbidity and mortality due to infection with this virus [4]. However, issues such as long-term toxicities, drug-drug interactions and emergence and transmission of drug-resistant viral strains represent a serious problem to long-term successful treatment that justify the search for new therapeutic approaches and drugs for the treatment of this infection [6].

Polyphenols or vegetable tannins are a diverse group of natural compounds characterized by the presence of multiple phenolic functionalities per molecule [7]. They are secondary metabolites produced by higher plants as a defense strategy against invading pathogens including insects, bacteria, fungi and viruses or as a response to environmental stress [8]. In addition, polyphenols serve to dissuade herbivores from eating plants due to their unpleasant and anti-nutritional properties [9].

Green tea (Camellia sinensis), one of the most popular beverages in the world, is an important source of polyphenols, especially flavonoids of the catechin-type. Among them, (-) epigallocatechin gallate (EGCG) is the most abundant (4060\%), followed by (-) epicatechin gallate (ECG, 10-20\%), (-) epigallocatechin (EGC, 10-20\%) and (-) epicatechin (EC, 4$6 \%)[10]$

The green tea catechins are well-known for their antioxidant properties [11] and their beneficial therapeutic effects against some forms of cancer [12] cardiovascular [13] and neurological diseases [14]. In addition many antimicrobial activities [15], such as antibacterial [16], antifungal [17] and antiviral [18] have been described for this group of molecules:

Nowadays it is generally accepted that the pyrogallol and galloyl groups, present in several natural tea catechins, are responsible for most of their antioxidant, anticancer and antimicrobial activities [19,20]. In fact, EGCG and ECG, having a 3-galloyl side-chain, showed higher antimicrobial activity and anticancer properties than catechins, like EC and EGC, that lack the galloyl moiety.

In the light of the wide range of biological activities attributed to natural green tea catechins they have been used as lead structures for the development of synthetic analogues. Among them, n-alkyl esters of gallic acid, also known as alkyl gallates, have become a focus of attention because of their antioxidant properties. In fact, they have been widely employed as antioxidant additives in both, food and pharmaceutical industry [21]. In addition, there are numerous studies demonstrating that alkyl gallates have a wide range of biological activities including anticancer [22], antibacterial [23], antifungal [24] and antiviral activity [25]. 
Taking into account that the pyrogalloyl and galloyl groups present in natural tea catechins and synthetic alkyl gallates are responsible for most of their biological activities we considered of particular interest the combination of two or more of these galloyl moieties, or other related phenolic substituents, in a single molecule as a novel class of synthetic alkyl gallates. We reasoned that this approach would allow obtaining molecules with enhanced biological activity with respect to the "classical" alkyl gallates (with only one galloyl residue per molecule). Here we report the synthesis of binary, tri- and penta- alkyl gallate analogues and their antiviral effects against a wide variety of viruses.

In these compounds gallic acid (3,4,5-trihydroxybenzoic acid) and its isomer 2,3,4-trihydroxybenzoic acid, together with other mono- and dihydroxybenzoyl residues have been used as phenolic substituents while linear or branched polyamines or polyalcohols of different lengths and architectures were used as scaffolds. These scaffolds allowed the introduction, on the same molecule of a variable number of phenolic residues (from two to five) and the modification of the distance and spatial distribution between them (Figure 1).<smiles></smiles>

$n=4-12$

$\mathrm{X}=\mathrm{O}, \mathrm{NH}$<smiles>O=C(NCCCN(CCCNC(=O)c1ccc(O)c(O)c1)C(=O)c1ccc(O)cc1)c1ccc(O)cc1</smiles>

$n=m$

$\mathrm{n} \neq \mathrm{m}$

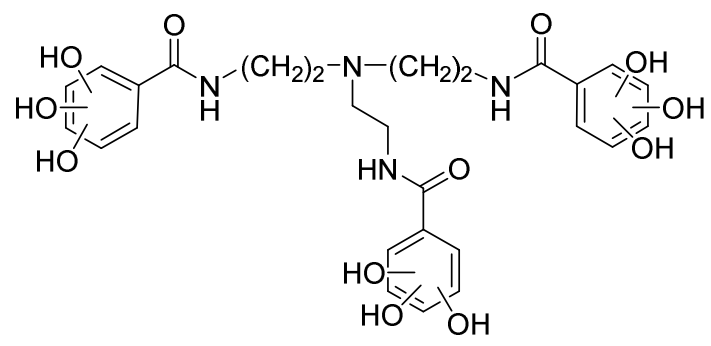

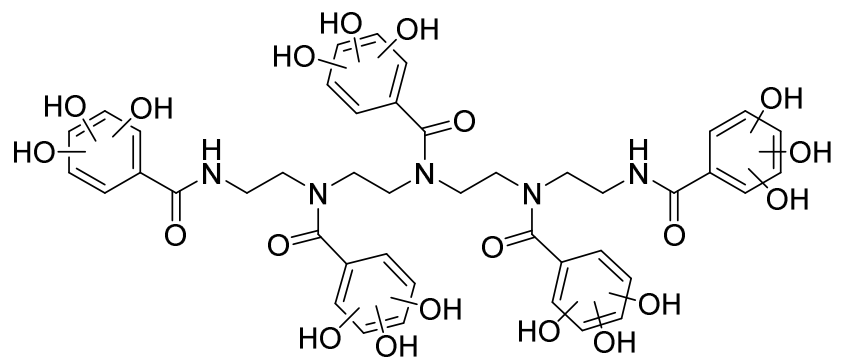

Fig. 1. Target linear and branched polyphenols

To determine the impact of the chemical structure on the antiviral activity we studied: $i)$ the nature of the linkage between the gallic acid residues and the hydrocarbon chain (ester or amide); ii) the number of galloyl units bound to a given scaffold; iii) the number and position of $\mathrm{OH}$ groups on the aromatic ring. 


\section{Results and discussion}

\subsection{Chemical results}

Firstly, several members of the well-known n-alkyl esters of gallic acid (alkyl gallates) (2-7) have been synthesized in our laboratory (Scheme 1) in order to be used as reference compounds in the biological evaluation. In our hands microwave conditions [26] prove superior than other more classical conditions [25d,27]. Briefly, gallic acid 1 with the appropriate alcohol and trace amounts of concentrated sulfuric acid as catalyst were microwave-irradiated during 50 min at $100{ }^{\circ} \mathrm{C}$ to give gallates 2-7 with excellent yields (82\%-98\%). Compared with the classical synthetic route, microwave conditions significantly reduced the reaction time $\left(50 \mathrm{~min}\right.$ at $100{ }^{\circ} \mathrm{C}$ versus $2-12 \mathrm{~h}$ at $\left.160{ }^{\circ} \mathrm{C}\right)$, increase the yields $(58 \%$ $80 \%$ versus $82 \%-98 \%$ ) and simplify the experimental protocol (use of Dean Stark or vacuum).<smiles>O=C(O)c1cc(O)c(O)c(O)c1</smiles>

1<smiles>CCCCCO</smiles>
$\mathrm{n}=1,3,4,5,7,11$

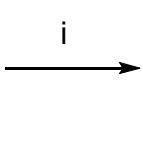<smiles>CCCCCOC(=O)c1cc(O)c(O)c(O)c1</smiles>

$2, \mathrm{n}=1, \quad 70 \%$

$3, n=3, \quad 97 \%$

$4, n=4, \quad 83 \%$

$\mathbf{5}, \mathrm{n}=5, \quad 98 \%$

$6, n=7, \quad 96 \%$

$7, n=11,82 \%$

Scheme 1. Synthesis of alkyl gallates 2-7 under microwave-irradiated conditions. Reagents and conditions: (i) $\mathrm{MW}_{2} \mathrm{H}_{2} \mathrm{SO}_{4}$ (cat.), $100{ }^{\circ} \mathrm{C}, 50 \mathrm{~min}$

With the aim to evaluate the relationship between the number of polyphenol moieties per molecule and the antiviral properties, a variable number (2, 3 and 5) of polyphenol residues were attached to different central scaffolds.

First, we prepared compounds 8-11 with two gallic acid residues at the terminal ends of the molecule (Scheme 2). To evaluate the influence of the length of the alkyl chain on the antiviral activity, different chain lengths were used to connect the two polyphenol subunits. It should be mentioned that the synthesis of some of these compounds has been previously described [22a, 22b, 28], however their antiviral activities were completely unknown. In the reported synthetic procedure a six-step route, involving protection of the phenolic functionalities, has been used. In our case a direct and shorter synthetic route involving only one-step reaction and non-protected phenol functionalities was attempted. Thus, in this route two equivalents of gallic acid was treated with the corresponding diols (1,4-butanodiol, 1,6-hexanodiol, 1,8-octanodiol and 1,12-dodecanodiol) in the presence of a catalytic amount of $p$-toluene sulfonic acid. The mixture was heated under reflux $\left(160{ }^{\circ} \mathrm{C}\right)$ resulting in compounds 8-11 with $28 \%-70 \%$ yields. Microwave-assisted conditions was also attempted for the synthesis of these compounds, however complex mixtures of compounds were obtained. 
<smiles>O=C(O)c1cc(O)c(O)c(O)c1</smiles><smiles>CCCCCO</smiles>

$n=4,6,8$ y 12<smiles>CCCCCCOC(=O)c1cc(O)c(O)c(O)c1</smiles>

8, $n=4, \quad 70 \%$

9, $\mathrm{n}=6, \quad 28 \%$

10, $\mathrm{n}=8, \quad 50 \%$

$11, n=12,52 \%$

Scheme 2. Synthesis of alkyl digallates 8-11. Reagents and conditions: (i) $p$-TSA (cat.), dioxane, $160{ }^{\circ} \mathrm{C}, 50 \mathrm{~min}$

Next, alkyl gallamides 18-22, containing amide bonds instead of ester bonds and various lengths of the alkyl chain, were also prepared. As described in Scheme 3, these compounds were synthesized by condensation of the commercially available OMe-protected gallic acid chloride 12 with the corresponding diamines (1,4-butanodiamine, 1,6-hexanodiamine, 1,8-octanodiamine, 1,10-decanodiamine and 1,12-dodecanodiamine). Reactions were performed in the presence of potassium carbonate using a biphasic system of ethyl acetate/water. This reaction allowed the synthesis of the OMeprotected derivatives 13-17 in excellent yields (77\%-98\%). Deprotection of the methyl ether derivatives using the Lewis acid boron tribromide gave the deprotected final compounds $\mathbf{1 8 - 2 2}$ in moderate to good yields (51-84\%).

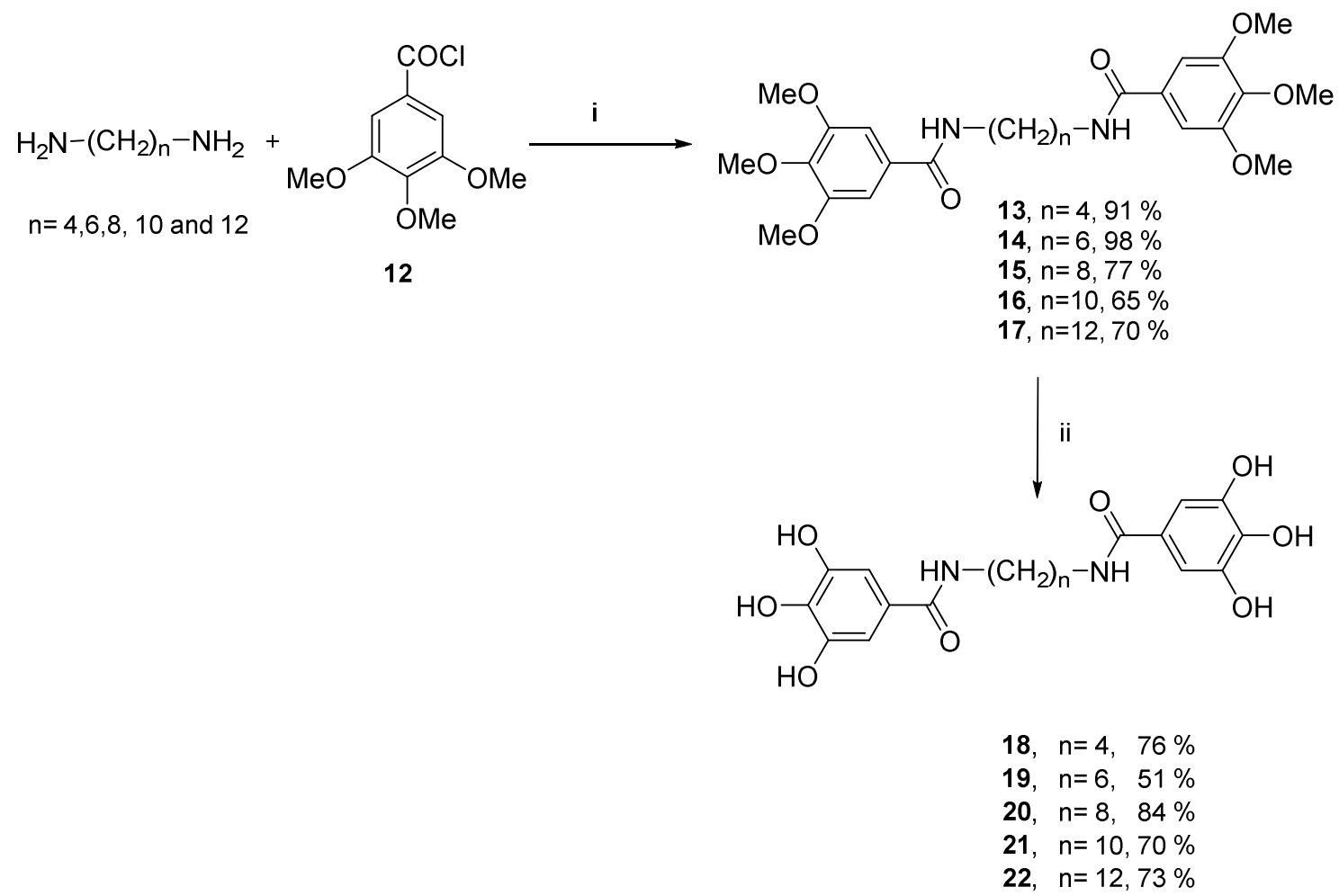

Scheme 3. Synthesis of alkyl digallamides18-22. Reagents and conditions: (i) $\mathrm{K}_{2} \mathrm{CO}_{3}, \mathrm{AcOEt} / \mathrm{H}_{2} \mathrm{O}$ (1:1) (ii) $\mathrm{BBr}_{3}, \mathrm{CH}_{2} \mathrm{Cl}_{2}$ 
The same synthetic methodology was applied for the synthesis of the OMe protected trigalloyl (23, 25 and 27) (Scheme 4) and pentagalloyl 29 (Scheme 5) derivatives that were obtained in 38\%-85\% yields. In this case, diethylenetriamine, spermidine, tris(2-aminomethyl)amine and tetraethylenepentamine were used as starting amines. Deprotection of the methyl ether derivatives 23, 25, 27 and 29 using the Lewis acid boron tribromide gave the corresponding deprotected final compounds 24, 26, 28 [29] and $\mathbf{3 0}$ in moderate to good yields (30-100\%).
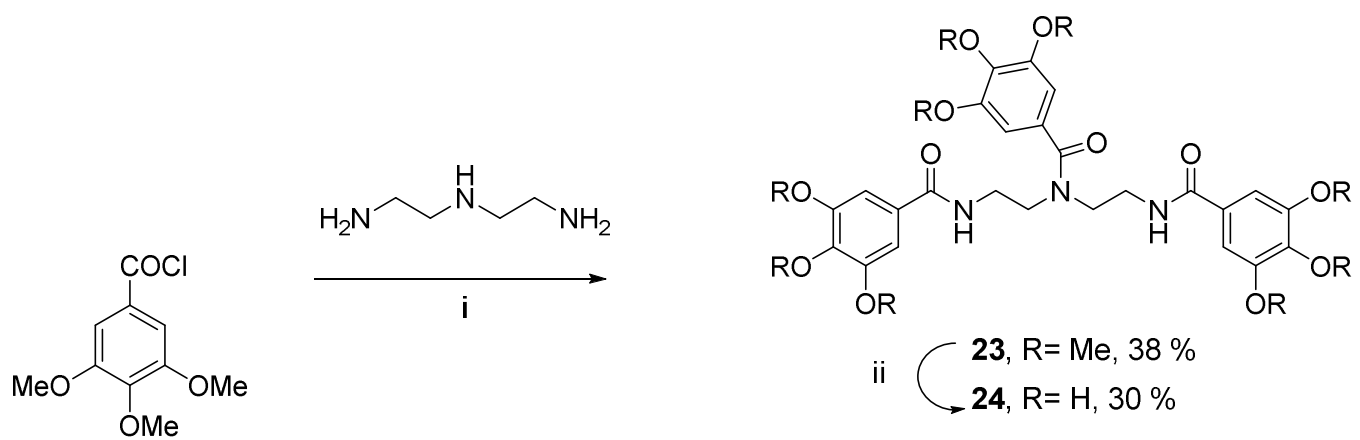

$$
\text { ii } \quad \begin{aligned}
& 23, R=M e, 38 \% \\
& 24, R=H, 30 \%
\end{aligned}
$$

12<smiles>NCCN(CCN)CCN</smiles><smiles>[R]Oc1cc(C(=O)NCCCCN(CCCCNC(=O)c2cc([R2])c([R])c([R])c2)C(=O)c2cc([R2])c([R2])c([R2])c2)cc([R2])c1[R2]</smiles><smiles>[R]Oc1cc(C(=O)I)cc([R20])c1[R20]</smiles><smiles></smiles> 
Scheme 4. Synthesis of branched trigallamides 24, 26 and 28. Reagents and conditions: (i) $\mathrm{K}_{2} \mathrm{CO}_{3}, \mathrm{AcOEt}_{2} \mathrm{H}_{2} \mathrm{O}$ (1:1) (ii) $\mathrm{BBr}_{3}, \mathrm{CH}_{2} \mathrm{Cl}_{2}$
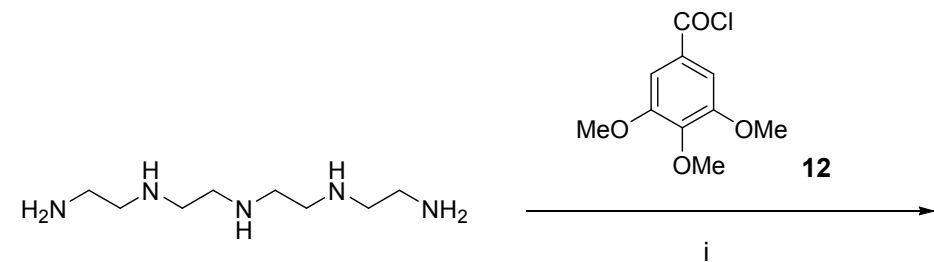

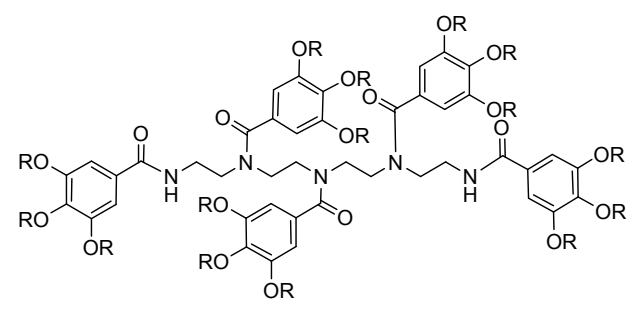

29, $\mathrm{R}=\mathrm{Me}, 85 \%$

30, $R=H, 100 \%$

Scheme 5. Synthesis of pentagallamide 30. Reagents and conditions: (i) $\mathrm{K}_{2} \mathrm{CO}_{3}, \mathrm{AcOEt} / \mathrm{H}_{2} \mathrm{O}$ (1:1) (ii) $\mathrm{BBr}_{3}, \mathrm{CH}_{2} \mathrm{Cl}_{2}$

In order to investigate the effect of the spatial distribution of the hydroxyl groups on the aromatic ring, the corresponding 2,3,4-trihydroxybenzoyl isomeric derivatives 32-45 (Scheme 6) were also synthesized. In this case, the 2,3,4-benzyl protected intermediate 31 was employed as starting compound (Scheme 6). In turn, intermediate 31 was prepared starting from commercially available 2,3,4-trihydroxycarboxylic acid by perbenzylation of the carboxylic acid and hydroxyl groups followed by saponification of the ester group [30]. Next, condensation of $\mathbf{3 1}$ with the corresponding alkyl amine in the presence of pyBOP and triethylamine, followed by deprotection of the benzyl ether derivatives using $\mathrm{H}_{2} / \mathrm{Pd}-\mathrm{C}$ gave the deprotected final compounds 37-41, 43 and 45 in moderate to good yields (35-61\%). Synthesis of compound 45 was described in the literature [29c] using a 2-mercaptothiazoline 2,3,4-trimethoxy benzoic acid derivative, instead of the benzyl protected intermediate $\mathbf{3 1}$ used by us. 


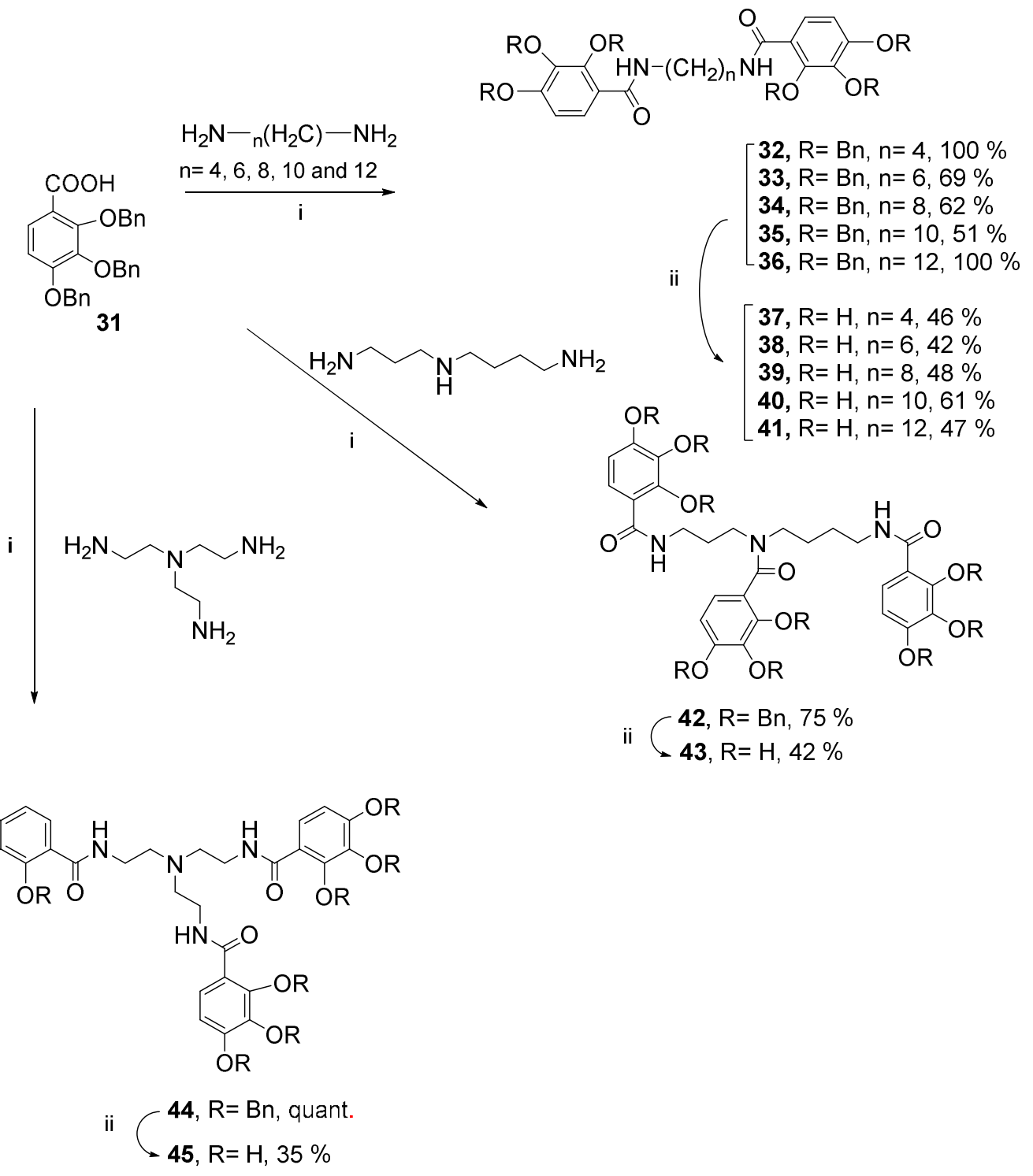

Scheme 6. Synthesis of 2,3,4-trihydroxybenzoyl derivatives 32-45 Reagents and conditions: (i) pyBOP, Et 3 N (ii) $\mathrm{H}_{2}, \mathrm{Pd} / \mathrm{C}$

Next, to determine the impact of the number of hydroxyl groups present on the aromatic ring on the antiviral activity compounds 50-52 and 57-59, with two or one hydroxyl groups, respectively were prepared (Schemes 7 and 8).

The dihydroxy-benzoyl analogues 50-52 (Scheme 7) were previously synthesized by different authors [31] although their antiviral properties were completely unknown. In our case a modification of the previously described procedures, that implies the use of pyBOP as coupling reagent, has been used for the synthesis of these compounds. In this reaction, the commercially available 2,3-dimethoxybenzoic acid 46 (Scheme 7) was used as starting material. Reaction of this intermediate with ethylene, tetramethylene and dodecamethylene diamines in the presence of pyBOP and triethylamine, 
followed by deprotection of the methyl ether derivatives 47-49 using the Lewis acid boron tribromide gave the deprotected final compounds 50-52 with excellent yields (81-99\%).<smiles>COc1cccc(C(=O)O)c1OC</smiles>

46

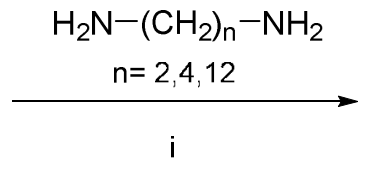

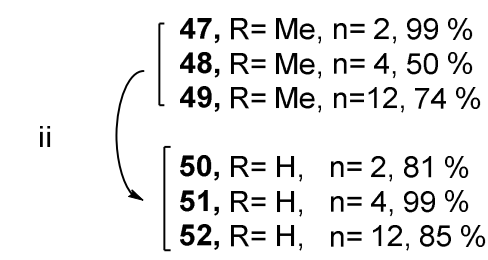

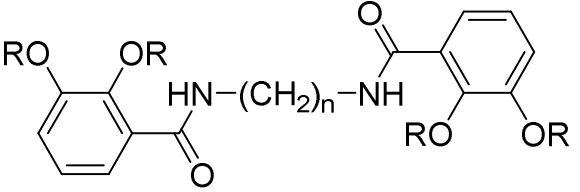

Scheme 7. Synthesis of 2,3-dihydroxybenzoyl derivatives 50-52. Reagents and conditions: (i) pyBOP, $\mathrm{Et}_{3} \mathrm{~N}$ (ii) $\mathrm{BBr}_{3}$, $\mathrm{CH}_{2} \mathrm{Cl}_{2}$

The coupling reagent, pyBOP, was also used for the synthesis of the monohydroxy benzoyl analogues $\mathbf{5 7 - 5 9}$ (Scheme 8). In this case the commercially available 2-benzyloxy salicylic acid $\mathbf{5 3}$ was used as starting material. Reaction of this intermediate with the corresponding alkyl amine in the presence of pyBOP, as coupling reagent, and triethylamine followed by deprotection of the benzyl ether derivatives 54-56, using $\mathrm{H}_{2} / \mathrm{Pd}-\mathrm{C}$, gave the deprotected final compounds 57$\mathbf{5 9}$ with good to excellent yields (69-92\%).

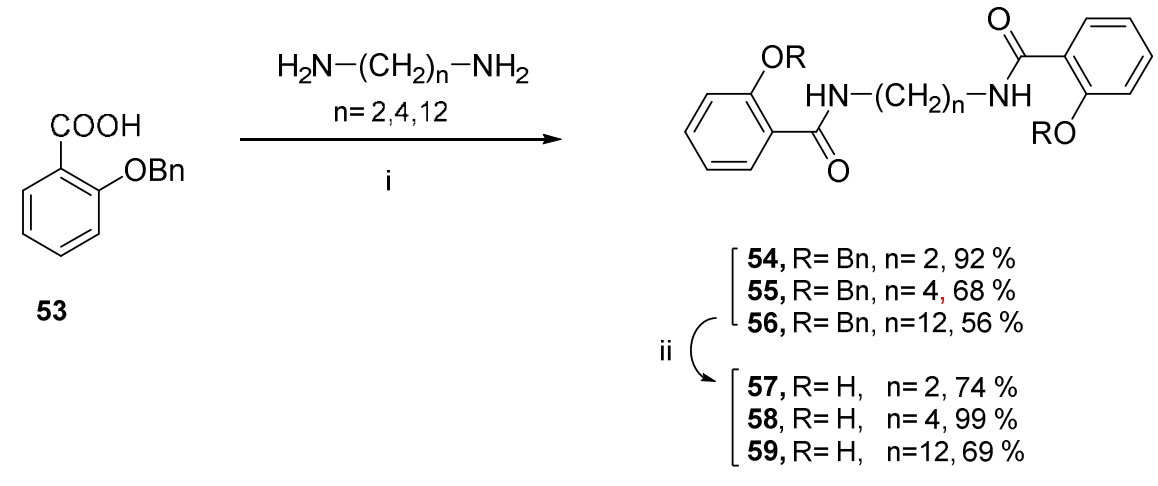

Scheme 8. Synthesis of 2-monohydroxybenzoyl derivatives 57-59. Reagents and conditions: (i) pyBOP, Et $3 \mathrm{~N}$ (ii) $\mathrm{H}_{2}, \mathrm{Pd} / \mathrm{C}$

As it will be later discussed in the Antiviral Evaluation section, alkylgallamide 41 (Scheme 6), containing a twelve methylene linker connecting two phenolic subunits at the ends, showed significant anti-HCV activity in cell culture. To complete the structure-activity relationship studies of this compound we prepared compounds $\mathbf{6 1}$, with a less lipophilic 
linker, and 63 with the phenolic OHs protected as OMe (Scheme 9). The synthesis of these compounds were accomplished by coupling of intermediates $\mathbf{3 1}$ and $\mathbf{6 2}$ with the corresponding amines in the presence of pyBOP ant triethylamine.<smiles>CCCCOc1ccc(C(=O)O)c(CBr)c1Br</smiles>

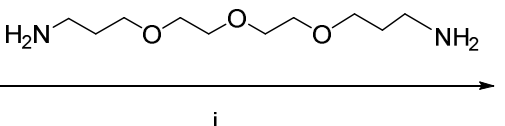

31

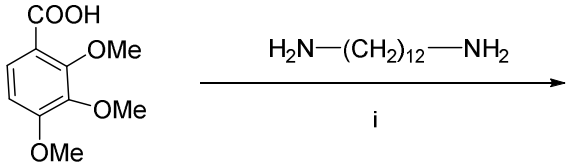

62<smiles>[R]Oc1ccc(C(=O)NCCCOCCOCCOCCCNCC(=O)c2ccc([R20])c([R20])c2[R])c([R])c1[R]</smiles>

ii

$60, R=B n, 57 \%$

61, $R=H, 73 \%$

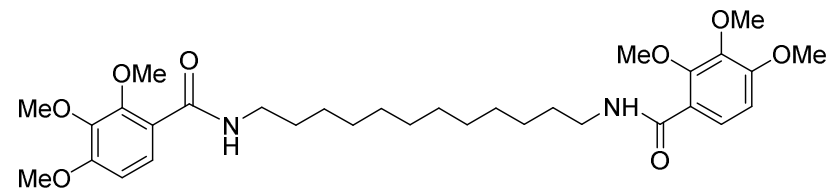

$63,72 \%$

Scheme 9. Synthesis of derivatives 61 and 63. Reagents and conditions: (i) pyBOP, $\mathrm{Et}_{3} \mathrm{~N}$ (ii) $\mathrm{H}_{2}, \mathrm{Pd} / \mathrm{C}$

\subsection{Biological results}

Firstly, the new synthetic phenolic derivatives have been evaluated for their in vitro inhibitory effects against a wide panel of viruses such as: vaccinia, vesicular stomatitis, Coxsackie B4, respiratory syncytial, para-influenza-3, reovirus, Sindbis, influenza A (H1N1, H3N2), Punta Toro, feline corona, feline herpes and Chikungunya. None of these compounds showed activity against these viruses.

Next, the new synthetic compounds were evaluated against HIV. Gallic acid (1), the commercially available natural polyphenols (EGCG, ECG, EGC and EC) and the "classical" alkyl gallates 2-7 were also included for comparative purpose. Compounds xxx and xxxx were also included as positive controls respectively.

None of the OMe- or OBn-protected compounds proved active at subtoxic concentrations (data not shown). These data point to the importance of unsubstituted phenolic OHs for activity.

Table 1 summarizes the results of the anti-HIV evaluation of the deprotected compounds.

Table 1. Inhibitory effect of test compounds against HIV-1 and HIV-2 in CEM cell cultures

\begin{tabular}{|llll|}
\hline & \multicolumn{2}{c|}{ EC $_{50}(\boldsymbol{\mu M})^{\mathbf{a}}$} & \multirow{2}{*}{$\mathbf{C C}_{\mathbf{5 0}}(\boldsymbol{\mu M})^{\mathbf{b}}$} \\
& HIV-1 $\left(\right.$ III $\left._{\mathbf{B}}\right)$ & HIV-2 $($ ROD) & \\
\hline $\mathbf{1}$ & $>50$ & $>50$ & $>250$ \\
EGCG & $>10$ & $>10$ & -- \\
EGG & $>50$ & $>50$ & $104 \pm 12.3$ \\
\hline
\end{tabular}




\begin{tabular}{|llll|} 
EC & $>250$ & $>250$ & $>250$ \\
\hline $\mathbf{2}$ & $>10$ & $>10$ & $23 \pm 0$ \\
$\mathbf{3}$ & $>10$ & $>10$ & $55 \pm 43$ \\
$\mathbf{4}$ & $14 \pm 5$ & $\geq 10$ & $47 \pm 38$ \\
$\mathbf{5}$ & $5.4 \pm 0.6$ & $6.6 \pm 1.1$ & $14 \pm 3$ \\
$\mathbf{6}$ & $>2$ & $>2$ & $11 \pm 8$ \\
$\mathbf{7}$ & $\geq 1$ & $\geq 1$ & $2.8 \pm 0.4$ \\
\hline $\mathbf{8}$ & $>10$ & $>10$ & $21 \pm 3$ \\
$\mathbf{9}$ & $\geq 10$ & $\geq 10$ & $22 \pm 0.4$ \\
$\mathbf{1 0}$ & $>10$ & $>10$ & $13 \pm 7$ \\
$\mathbf{1 1}$ & $4.6 \pm 0.1$ & $>10$ & $4.7 \pm 0.3$ \\
\hline $\mathbf{1 8}$ & $5.2 \pm 0.9$ & $>10$ & $23 \pm 1$ \\
$\mathbf{1 9}$ & $>10$ & $>10$ & $72 \pm 39$ \\
$\mathbf{2 0}$ & $>10$ & - & $51 \pm 28$ \\
$\mathbf{2 1}$ & $>50$ & $>50$ & $86 \pm 12$ \\
$\mathbf{2 2}$ & $19 \pm 12$ & $26 \pm 2.1$ & $58 \pm 7.8$ \\
\hline $\mathbf{2 4}$ & $>10$ & $>10$ & $34 \pm 14$ \\
$\mathbf{2 6}$ & $18 \pm 16$ & -- & $107 \pm 0.7$ \\
$\mathbf{2 8}$ & $10 \pm 0.0$ & -- & $54 \pm 33$ \\
$\mathbf{3 0}$ & $4.9 \pm 0.6$ & $>10$ & $21 \pm 1.4$ \\
\hline $\mathbf{3 7}$ & $>10$ & $>10$ & $109 \pm 87$ \\
$\mathbf{3 8}$ & $>50$ & $>50$ & $102 \pm 4.2$ \\
$\mathbf{3 9}$ & $>50$ & $>50$ & $82 \pm 11$ \\
$\mathbf{4 0}$ & $>50$ & $>50$ & $100 \pm 4.9$ \\
$\mathbf{4 1}$ & $>10$ & $>10$ & $55 \pm 21$ \\
$\mathbf{4 3}$ & $2.6 \pm 2.3$ & $>10$ & $27 \pm 0.7$ \\
$\mathbf{4 5}$ & $2.5 \pm 1.9$ & $>10$ & $28 \pm 9.3$ \\
\hline $\mathbf{5 0}$ & $>10$ & $>10$ & $19 \pm 5.5$ \\
$\mathbf{5 1}$ & $>2$ & -- & $5.2 \pm 0.8$ \\
$\mathbf{5 2}$ & $>2$ & $>2$ & 4.8 \\
$\mathbf{5 7}$ & $>10$ & $>10$ & $25 \pm 2.8$ \\
$\mathbf{5 8}$ & $>10$ & -- & $35 \pm 3.5$ \\
$\mathbf{5 9}$ & $>250$ & $>250$ & 248 \\
\hline $\mathbf{6 1}$ & $>50$ & $>50$ & $81 \pm 11$ \\
\hline & & & \\
\hline $\mathbf{X x x x x x ( p o s i t i v e}$ & & & \\
$\mathbf{c o n t r o l})$ & & & \\
& & & \\
\hline & & & \\
\hline
\end{tabular}

a $50 \%$ Effective concentration, or compound concentration required to inhibit HIV-induced cytopathicity by $50 \%$. b $50 \%$ Cytostatic concentration, or compound concentration required to inhibit cell proliferation (CEM) by $50 \%$. Data are the mean \pm S.D. of at least 2 to 3 independent experiments

As it was shown in Table 1 gallic acid (1) did not show any anti-HIV activity up to $50 \mu \mathrm{M}$. Also the natural polyphenols of the catechin-type EGCG, ECG, EGC and EC were inactive at subtoxic concentrations.

Within the group of alkyl gallates, compounds 2 to 7, only pentyl and hexyl gallates (4 and 5) were endowed with anti-HIV-1 and -HIV-2 activity below, but close to subtoxic concentrations. Although their activity is close to the toxicity threshold (antiviral selectivity index $\sim 2$ to 4 ) these data are important because they represent a first hint of activity in this 
compound series. Moreover, and taking into consideration that gallic acid as such did not exhibit any antiviral activity against HIV, this result indicates that the alkyl moiety plays an important role in the eventual antiviral activity.

The digallates $\mathbf{8}$ to $\mathbf{1 1}$ could not improve the activities obtained for the monoesters.

Within the group of alkyl digallamides (18 to 22), the most active compound was $\mathbf{1 8}$, with a spacer of 4 methylenes, followed by $\mathbf{2 2}$ with a chain of 12 methylenes, as spacer. Again, the antiviral selectivity index was around 3 to 4 , as observed for the alkyl gallates.

Within the group of compounds with $3(\mathbf{2 4}, \mathbf{2 6}, \mathbf{2 8})$ or $5(\mathbf{3 0})$ units of gallic acid, the most active agent was $30\left(\mathrm{EC}_{50}\right.$ HIV-1: $4.9 \mu \mathrm{M}$; selectivity index 4). The spermidine derivative 26 showed an $\mathrm{EC}_{50}$ of $18 \mu \mathrm{M}$, but proved the least toxic compound in this series $\left(\mathrm{CC}_{50}: 107 \mu \mathrm{M}\right)$, resulting in a selectivity index of $\sim 6$.

The alkyl amides $\mathbf{3 7}$ to $\mathbf{4 1}$ with only two phenolic rings were inactive at subtoxic concentrations. Interestingly, branched compounds $\mathbf{4 3}$ and $\mathbf{4 5}$ bearing 3 phenolic rings with hydroxyl groups at positions 2,3,4 were endowed with the most pronounced anti-HIV activity among all compounds evaluated $\left(\mathrm{EC}_{50}\right.$ : 2.5-2.6 $\left.\mu \mathrm{M}\right)$. Activity showed by these compounds are below the toxicity threshold $\left(\mathrm{CC}_{50}: 27-28 \mu \mathrm{M}\right)$ ), resulting in selectivity indexes of $\left.\sim 10\right)$.

The compounds 50-52 and 57-59 in which gallic acid has been replaced by aromatic rings with only 2 or 1 hydroxyl groups, respectively, were inactive.

Importantly, the spermidine derivative 26, substituted with 3 gallic acid moieties was less active than compound $\mathbf{4 3}$ substituted with three 2,3,4-trihydroxyphenyl rings. Similarly, compound 28 containing a tris(2-aminoethyl)amine skeleton substituted with 3 gallic acid moieties proved less active than 45 with the same skeleton and three 2,3,4trihydroxy phenyl rings showing that the 2,3,4-trihydroxyphenyl moiety provides better anti-HIV activities than the gallic acid moiety.

Next, the new synthetic polyphenols were also evaluated for their in vitro inhibitory effects on hepatitis $\mathrm{C}$ virus replication. Table 2 summarizes the results of the anti-hepatitis C virus evaluation of the test compounds. The HCV NS3 protease inhibitor (Telaprevir) was included as positive control.

Table 2. Antiviral effect of the test compounds on hepatitis $\mathrm{C}$ virus replication in the Huh 5-2 replicon system

\begin{tabular}{|llll|}
\hline Compound & $\mathbf{E C}_{\mathbf{5 0}}(\boldsymbol{\mu M})^{\mathbf{a}, \mathbf{d}}$ & $\mathbf{E C}_{\mathbf{9 0}}(\boldsymbol{\mu} \mathbf{M})^{\mathbf{b , d}}$ & $\mathbf{C C}_{\mathbf{5 0}}(\boldsymbol{\mu} \mathbf{M})^{\mathbf{c}, \mathbf{d}}$ \\
\hline \hline $\mathbf{2}$ & 19 & $>45$ & 45 \\
$\mathbf{3}$ & 13 & $>29$ & 29 \\
$\mathbf{4}$ & 14 & $>50$ & $>50$ \\
$\mathbf{5}$ & 9.0 & $>50$ & $>50$ \\
$\mathbf{7}$ & 0.4 & 1.8 & 8.9 \\
\hline $\mathbf{8}$ & 39 & $>50$ & $>50$ \\
$\mathbf{9}$ & 16 & --- & $>50$ \\
$\mathbf{1 0}$ & 17 & 55 & 80 \\
$\mathbf{1 1}$ & 6.5 & 37 & $>50$ \\
\hline $\mathbf{1 8}$ & 18 & $>29$ & 29 \\
$\mathbf{1 9}$ & 11 & $>24$ & 24 \\
$\mathbf{2 0}$ & 23 & $>50$ & $>50$ \\
\hline
\end{tabular}




\begin{tabular}{|llll|}
\hline $\mathbf{2 1}$ & 20 & --- & 47 \\
$\mathbf{2 2}$ & 27 & $>100$ & $>100$ \\
\hline $\mathbf{2 8}$ & $>2.9$ & $>2.9$ & $>2.9$ \\
$\mathbf{3 0}$ & 34 & $>50$ & $>50$ \\
\hline $\mathbf{3 7}$ & 15 & $>50$ & $>50$ \\
$\mathbf{3 8}$ & 14 & --- & 32 \\
$\mathbf{3 9}$ & 25 & --- & 34 \\
$\mathbf{4 0}$ & 11 & --- & $>100$ \\
$\mathbf{4 1}$ & 2.5 & 6.1 & $>100$ \\
\hline $\mathbf{4 3}$ & 34 & $>50$ & $>50$ \\
$\mathbf{4 5}$ & $>5.5$ & $>5.5$ & $>3.7$ \\
\hline $\mathbf{5 2}$ & 2.0 & 4.8 & 108 \\
$\mathbf{5 8}$ & 11 & --- & $>49$ \\
$\mathbf{5 9}$ & 4.7 & $>6.7$ & $>6.7$ \\
$\mathbf{6 1}$ & 28 & --- & 49 \\
\hline $\mathbf{6 3}$ & $>3.5$ & --- & 5.4 \\
\hline Telaprevir (VX-950) & 2.8 & --- & 47 \\
\hline
\end{tabular}

${ }^{\mathrm{a}} \mathrm{EC}_{50}=50 \%$ effective concentration (concentration at which $50 \%$ inhibition of virus replication is observed).

${ }^{\mathrm{b}} \mathrm{EC}_{90}=90 \%$ effective concentration (concentration at which $90 \%$ inhibition of virus replication is observed).

${ }^{\mathrm{c}} \mathrm{CC}_{50}=50 \%$ cytostatic/cytotoxic concentration (concentration at which $50 \%$ adverse effect is observed on the host cell).

As it was shown for HIV none of the OMe- or OBn-protected compounds proved active at subtoxic concentrations (data not shown). These data point again to the importance of unsubstituted phenolic OHs as a requisite for antiviral activity. Table 2 summarizes the results of the anti-hepatitis $\mathrm{C}$ virus evaluation of the unprotected compounds.

The "classical" alkyl gallate derivatives (2-5) showed activity against hepatitis $\mathrm{C}$ virus, albeit at concentrations that were close to the cytotoxic concentrations for the cells. Interestingly alkyl gallate 7, with a 12 methylene linker, showed an activity $\left(\mathrm{EC}_{50}=0.4 \mu \mathrm{M}\right)$ far beneath the toxicity threshold $\left(\mathrm{CC}_{50}>8.9\right)$, resulting in a selectivity index of $>22$.

With respect to the alkyl digallates 8-11 a tendency for the best efficiency is observed for compounds with longer alkyl chains. For instance, an increase in activity is observed when the alkyl length is expanded from $\mathrm{C}_{4}(\mathbf{8})$ to $\mathrm{C}_{12}(\mathbf{1 1})$. The most active compound (11) has the highest anti-HCV selectivity ( $>7)$.

Among the alkyl amides of gallic acid 18-22 a relationship between the anti-hepatitis $\mathrm{C}$ virus activity and the number of carbons of the alkyl chain could not be found. Instead, a correlation between the lenght of the alkyl moiety and the anti$\mathrm{HCV}$ activity was found for the amide derivatives 37-41, containing two 2,3,4-trihydroxy benzoyl moieties at the two ends of the molecule, and $\mathbf{5 2}$ with two 2,3 -dihydroxy benzoyl moieties. Among these compounds, the best antiviral efficiency was observed for compounds $\mathbf{4 1}$ and $\mathbf{5 2}$ containing a $\mathrm{C}_{12}$ polymethylene linker. Compound $\mathbf{5 2}\left(\mathrm{EC}_{50}=2.0 \mu \mathrm{M} ; \mathrm{CC}_{50}=\right.$ 108) with two contiguous hydroxyl groups on the aromatic ring is the most selective of this series (selectivity index: 54). Compound 41, with three consecutive hydroxyl groups in the 2,3,4 position on the aromatic ring, also showed an activity $\left(\mathrm{EC}_{50}=2.5 \mu \mathrm{M}\right)$ far beneath the toxicity threshold $\left(\mathrm{CC}_{50}>100\right)$, resulting in a selectivity index of $>40$. The comparable potency of both compounds indicates that the "extra" hydroxyl group present in $\mathbf{4 1}$ is not crucial for the activity. 
Two related analogues of $\mathbf{4 1}$, compounds $\mathbf{6 1}$ and $\mathbf{6 3}$, have been prepared to assess the influence of the lipophilicity of the linking alkyl chain and the $\mathrm{OH}$ groups on the anti-HCV activity. The polyethylene glycol derivative $\mathbf{6 1}$ with a less lipophilic linker, was markedly less active than compound 41, with a 12 methylene linker. No anti-HCV activity was observed with compound $\mathbf{6 3}$ with the phenolic $\mathrm{OHs}$ protected as OMe. This result clearly demonstrates that the free $\mathrm{OH}$ groups - alike HIV - play an important role in the anti-HCV activity and might also contribute to reduce cell toxicity.

Interestingly, alkyldigallamide 22 was less active than compound $\mathbf{4 1}$ revealing that the 2,3,4-trihydroxy phenyl moiety provides a better antiviral activity than the gallic acid moiety. These findings are consistent with previous observations made for HIV.

Compound 59, containing a $\mathrm{C}_{12}$ polymethylene linker and only one single $\mathrm{OH}$ group on the terminal aromatic rings was only active at toxic concentrations. The inactivity of $\mathbf{5 9}$ (with only $1 \mathrm{OH}$ on the aromatic ring) is in clear contrast with the activity shown by $\mathbf{4 1}$ and $\mathbf{5 2}$ (with 2 and $3 \mathrm{OHs}$ on the aromatic ring) revealing that the presence of at least 2 hydroxyl groups in a contiguous position on the aromatic ring is important for antiviral activity/selectivity.

Branched compounds 28, 43 and $\mathbf{4 5}$ with 3 galloyl or 2,3,4-trihydroxybenzoyl groups do not improve the antiviral efficacy of the linear compounds of equivalent length $(\mathbf{1 9}, \mathbf{2 0}, \mathbf{3 8}$ and 39) with only two galloyl or 2,3,4-trihydroxybenzoyl groups, showing that the antiviral efficacy was not increased by the introduction of an extra (third) polyphenolic moiety. The same was observed for compound $\mathbf{3 0}$ bearing 5 galloyl groups, with respect to $\mathbf{2 1}$ and $\mathbf{2 2}$ of equivalent size.

In summary, with respect to the anti-hepatitis $\mathrm{C}$ virus activity, our structure-activity relationship studies clearly show that the activity seems to be related with the lipophilicity and hydroxyl substitution pattern. The most noticeable finding was the anti-hepatitis $C$ virus activity shown by compounds $\mathbf{4 1}$ and $\mathbf{5 2}$ containing a 12 polymethylene chain and two 2,3 di- or 2,3,4 tri-hydroxybenzoyl groups located at the ends of the molecule, and leading to agents with a pronounced antiHCV activity and selectivity. The "classical" alkyl gallate 7 also shows significant activity (six and five-fold higher than those of $\mathbf{4 1}$ and $\mathbf{5 2}$ respectively) but its notorious toxicity makes it less attractive as lead compound.

Compounds tested can inadvertently inhibit heterologous elements such as the encephalomyocarditis virus (EMCV) internal ribosome-entry site (IRES) or the neomycin phosphotransferase (neo) that are required for the proper translation of the HCV polyprotein in the assay system or to keep the HCV subgenomic replicon persistently in cells, respectively. Therefore we evaluated a representative member of the compounds reported in this study, namely 41, in different replicon systems. On the one hand we used Huh 9-13 HCV replicons that have the same genetic make-up as Huh 5-2 replicons, but differ in their composition of cell culture adaptive mutations, the absence of a luciferase reporter gene and the higher HCV RNA content as compared to Huh 5-2 cells [32]. Furthermore, we included a subgenomic replicon contained in HuH6 cells that again have a similar genetic make-up as Huh 5-2 replicons, but $(i)$ replicate in a different cell line (HuH6 cells instead of Huh-7 cells) and (ii) carry different adaptive mutations. Moreover, in HCV subgenomic replicon containing HuH6 cells, replicon replication is not inhibited by IFN- $\gamma$ and viral RNA replication is independent from cell proliferation [33].

Compound 41 proved to be active in both Huh 9-13 and HuH6 HCV subgenomic replicon containing cells at $\mathrm{EC}_{50^{-}}$ values of $8.4 \pm 1.6 \mu \mathrm{M}$ and $33 \mu \mathrm{M}$, respectively, as determined by RT-qPCR. In both replicon containing cells 41 did not show any effect on the proliferation and metabolism of the host cell as determined by the MTS assay $\left(\mathrm{CC}_{50}>100 \mu \mathrm{M}\right)$ at the concentrations tested. The obtained values are in the same range as for the Huh 5-2 HCV subgenomic replicon containing cells. These findings exclude an inhibitory effect on the luciferase expressed by the HCV subgenomic replicons 
in Huh 5-2 cells and also show that inhibition is independent of the genetic make-up of the replicon and of the cell line used.

As reported previously HCV subgenomic replicon replication is highly dependent on cell proliferation [33]. Hence, any compound that can induce a cytostatic effect on cell growth could result indirectly in inhibition of HCV subgenomic replicon replication [34]. At the concentrations tested none of the compounds showed marked inhibition of cell growth, as apparent from the MTS assay (see Table 2). However, microscopic examination did highlight reduced cell numbers and altered cell morphology for most of the phenolic derivatives tested (as exemplified in Figure 2 for 41).

Furthermore HCV replication is highly dependent on the cellular lipid metabolism [35]. Any perturbation of the lipid metabolism, for example inhibition of fatty acid oxidation, might result indirectly in the inhibition of HCV replication [36]. Candidate drugs can perturb the lipid metabolism of a cell in different ways, for example by inducing phospholipidosis and steatosis, as reviewed in [37]. To assess if the compounds studied altered the cellular lipid metabolism we used Nile Red staining to assess the ability of compound $\mathbf{4 1}$ to induce phospholipidosis or drug induced steatosis.

Cells treated with a serial dilutions of compound $\mathbf{4 1}$ were analyzed using Nile red staining to visualize the intracellular accumulation of neutral lipids (hallmark of phospholipidosis) and charged lipids. Overall Nile Red staining showed that derivative 41 significantly reduced cell growth at concentrations between 33-100 $\mu \mathrm{M}$. Furthermore these treated cells show a higher charged lipid content, as apparent of the increased cytoplasmic red stain, and an apparent rounded cell shape (Figure 2, panels A, B) as compared to the mock-treated cells (Figure 2, panel F). At lower concentrations (in the same range as the $\mathrm{EC}_{50}$ and $\mathrm{EC}_{90}$-values) derivative $\mathbf{4 1}$ did not affect the size nor the number of the lipid droplets represented by the green dots in Nile Red stained cells and had no observable effect on cell number and cellular shape. These observations suggest that the alteration of cell morphology and charged lipid content of the cell by 41 at concentrations $(\geq 33 \mu \mathrm{M})$ that are higher than those required to markedly inhibit HCV replication $\left(\mathrm{EC}_{50}: 2.5 \mu \mathrm{M}\right)$.

All of these findings led us to conclude that compound $\mathbf{4 1}$ can be a useful tool to understand the biology of HCV infection. Alternatively it will be a useful prototype for the development of novel HCV therapeutics.

With respect to the mechanism of action of $\mathbf{4 1}$ it is intriguing to speculate what structural features (long polymethylene linker and two phenolic moieties at the ends of the molecule) might contribute to its inhibitory action. As pointed out by several studies most of the bioactivities showed by the natural green tea catechins and synthetic alkyl gallates have been attributed to their antioxidant, free radical scavenging and metal chelating properties (iron, manganese, vanadium, copper, aluminium, calcium, etc...) [7c].Another important aspect of these molecules that has special significance for their bioactivity is their amphipatic character. This property is due to the presence in their structures of hydrophobic aromatic rings and hydrophilic hydroxyls and allow them to stablish interactions with biologically relevant molecules such as proteins and polysaccharides [7c-k].

Taking into account the above general considerations we might speculate that the compound $\mathbf{4 1}$ might inhibit various stages in the HCV life cycle by targeting key non-structural HCV proteins such as NS3/4A protease, NS5B RNAdependent RNA polymerase and NS5A. In addition it might inhibit the HCV/host cell fusion process by targeting structural proteins on the HCV surface. Moreover the antioxidant properties of the phenolic rings present in $\mathbf{4 1}$ can affect host cell factors that are of importance in the replication of $\mathrm{HCV}$. 

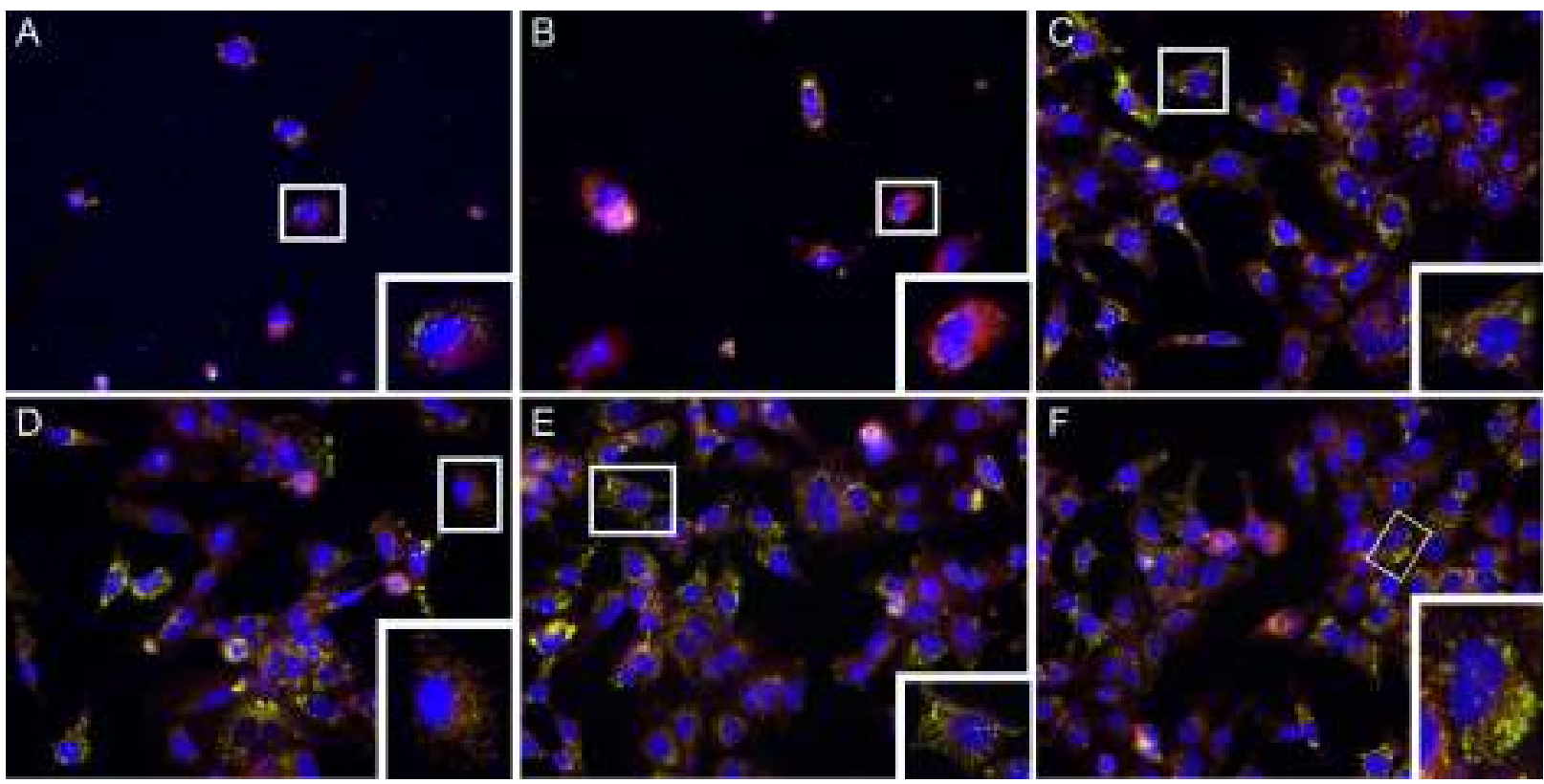

Fig 2. Huh 9-13 cells were treated with different concentrations of derivative $\mathbf{4 1}$ (Panel A. $100 \mu \mathrm{M}, \mathrm{B} .33 \mu \mathrm{M}, \mathrm{C} .11 \mu \mathrm{M}, \mathrm{D} .4$ $\mu \mathrm{M}$, E. $1 \mu \mathrm{M}$ ) or mock treated (Panel F) and stained with Nile Red. Boxes highlight cells that are magnified in the insert of each panel. Nile Red stains both neutral lipids (green color) and phospholipids (red color).

\section{Conclusions}

We have synthesized different series of phenolic acid derivatives in which gallic acid (3,4,5-trihydroxybenzoic acid) and its isomer 2,3,4-trihydroxybenzoic acid, together with other mono- and dihydroxybenzoyl residues have been used as phenolic substituents and linear polyamines or polyalcohols as scaffolds. The compounds showed preferential activity against HIV and HCV.

In general, the presence of free phenolic OHs is of crucial importance for the antiviral activity since the compounds with the phenolic OHs protected as OMe or OBn were, as a rule, inactive against HIV and HCV.

With respect to the anti-HIV activity it was shown that tripodal compounds, with three phenolic moieties, showed higher activities than linear compounds with only one or two.

With respect to the anti-hepatitis $C$ virus activity, the most notable finding was the selective anti-hepatitis $C$ virus activity shown by compounds $\mathbf{4 1}$ and $\mathbf{5 2}$ containing a 12-polymethylene chain and two 2,3 di- or 2,3,4 tri-hydroxybenzoyl groups located at the ends of the molecule. At least two contiguous hydroxyl groups on the aromatic ring seem to be important for activity since the compounds with only one $\mathrm{OH}$ on the aromatic ring were inactive.

Interestingly, compounds bearing 2,3,4-trihydroxy benzoyl moieties were more active against both HIV and HCV than compounds substituted with galloyl groups. This observation led us to conclude that the 2,3,4-trihydroxyphenyl 
moiety provides better antiviral activities than the gallic acid moiety. This moiety might serve for the further rational exploration of compounds with anti-HCV/HIV properties.

Further studies are needed to develop derivatives with improved antiviral activity and to determine how these compounds inhibit HCV.

\section{Materials and methods}

\section{Synthesis}

Microwave assisted conditions for the synthesis of alkyl gallates 2-7

A microwave vial was loaded with gallic acid $1(0.3 \mathrm{mmol}, 50 \mathrm{mg})$, the corresponding alcohol $(0.9 \mathrm{mmol})$, and concentrated $\mathrm{H}_{2} \mathrm{SO}_{4}(0.07 \mathrm{~mL})$. The reaction vessel was sealed and irradiated in a microwave reactor at $100{ }^{\circ} \mathrm{C}$ for 50 minutes. After cooling, volatiles were evaporated to dryness and the residue was dissolved in ethyl acetate $(30 \mathrm{~mL})$ and washed successively with saturated solutions of $\mathrm{NaHCO}_{3}(3 \times 20 \mathrm{~mL})$ and $\mathrm{NaCl}(1 \times 20 \mathrm{~mL})$. The organic layer was dried over anhydrous $\mathrm{Na}_{2} \mathrm{SO}_{4}$, filtered and concentrated under vacuum. The residue was then purified by column chromatography using hexane/EtOAc, (3:7) as the eluent. Melting points and characterization of compounds 2-7 were consistent with those found in the literature [25d]. In our case, the following yields were obtained: 2 (70\%), 3 (97\%), 4 (83\%), 5 (98\%), $6(96 \%), 7(82 \%)$.

\section{Tetramethylene-1,4-diyl-bis-(3,4,5-trihydroxybenzoate) (8)}

Gallic acid 1 (3.3 mmol, $566 \mathrm{mg})$, 1,4-butanediol (1.1 mmol, $100 \mathrm{mg}$ ) and a catalytic amount of $p$-toluensulfonic acid were dissolved in dioxane $(5 \mathrm{~mL})$ in a distillation system. The mixture was heated at $160{ }^{\circ} \mathrm{C}$ distilling the solvent which is continuously refilled until the reaction was completed. The reaction mixture was allowed to reach room temperature and then was cooled by a water-ice bath to give a precipitate that was filtered and washed with gently quantities of diethyl ether to give $305 \mathrm{mg}(70 \%)$ of 8 as a white solid; m.p. 221-222 ${ }^{\circ} \mathrm{C} .{ }^{1} \mathrm{H}-\mathrm{NMR}\left[\left(\mathrm{CD}_{3}\right)_{2} \mathrm{CO}, 300 \mathrm{MHz}\right] \delta 1.89\left(\mathrm{~m}, 4 \mathrm{H}, \mathrm{CH}_{2}\right)$, $4.30\left(\mathrm{~m}, 4 \mathrm{H}, \mathrm{OCH}_{2}\right), 7.14(\mathrm{~s}, 4 \mathrm{H}, \mathrm{ArH}), 8.07(\mathrm{~s}, 2 \mathrm{H}, \mathrm{OH}), 8.27(\mathrm{~s}, 4 \mathrm{H}, \mathrm{OH}) .{ }^{13} \mathrm{C}-\mathrm{NMR}\left[\left(\mathrm{CD}_{3}\right)_{2} \mathrm{CO}, 75 \mathrm{MHz}\right] \delta: 27.2\left(\mathrm{CH}_{2}\right)$, $65.7\left(\mathrm{CH}_{2}\right), 110.6(\mathrm{CH}), 122.6(\mathrm{C}), 139.7(\mathrm{C}), 147.0(\mathrm{C}), 168.0(\mathrm{CO}) . \mathrm{MS}(\mathrm{ES}+): \mathrm{m} / \mathrm{z} 395.3(\mathrm{M}+\mathrm{H})^{+}$. Anal. $\mathrm{C}_{18} \mathrm{H}_{18} \mathrm{O}_{10}(\mathrm{C}$, $\mathrm{H}, \mathrm{N}, \mathrm{O})$.

\section{Hexamethylene-1,6-diyl-bis-(3,4,5-trihydroxybenzoate) (9)}

Characterization of this compound in the literature was incomplete and NMR was registered in $\mathrm{CDCl}_{3}$ [22b] and DMSO [22a]. Missing data (melting point) and NMR in acetone were now included.

In a procedure analogous to that described for compound $\mathbf{8}$, gallic acid 1 (3.0 mmol, $510 \mathrm{mg})$ and 1,6-hexanediol (1.0 mmol, $118 \mathrm{mg})$ afforded $83 \mathrm{mg}(28 \%)$ of 9 as a white solid; m.p. $212-215{ }^{\circ} \mathrm{C} .{ }^{1} \mathrm{H}-\mathrm{NMR}\left[\left(\mathrm{CD}_{3}\right)_{2} \mathrm{CO}, 300 \mathrm{MHz}\right] \delta 1.50(\mathrm{~m}$, 4H, $\left.\mathrm{CH}_{2}\right), 1.74\left(\mathrm{~m}, 4 \mathrm{H}, \mathrm{CH}_{2}\right), 4.23\left(\mathrm{t}, J=6.5 \mathrm{~Hz}, 4 \mathrm{H}, \mathrm{OCH}_{2}\right), 7.14$ (s, 4H, ArH), 8.22 (bs, OH). MS (ES+): m/z 423 $(\mathrm{M}+\mathrm{H})^{+}$. Anal. $\mathrm{C}_{20} \mathrm{H}_{22} \mathrm{O}_{10}(\mathrm{C}, \mathrm{H}, \mathrm{N}, \mathrm{O})$. 
Characterization of this compound in the literature was incomplete and NMR was registered in $\mathrm{CDCl}_{3}$ [22b] and DMSO [22a]. Missing data (melting point) and NMR in acetone were now included.

In a procedure analogous to that described for compound $\mathbf{8}$, gallic acid 1 (3.0 mmol, $510 \mathrm{mg})$ and 1,8-octanediol (1.0 mmol, $146 \mathrm{mg}$ ) afforded $221 \mathrm{mg}(50 \%)$ of 10 as a white solid; m.p. 98-101 ${ }^{\circ} \mathrm{C} .{ }^{1} \mathrm{H}-\mathrm{NMR}\left[\left(\mathrm{CD}_{3}\right)_{2} \mathrm{CO}, 300 \mathrm{MHz}\right] \delta 1.50(\mathrm{~m}$, $\left.8 \mathrm{H}, \mathrm{CH}_{2}\right), 1.74\left(\mathrm{~m}, 4 \mathrm{H}, \mathrm{CH}_{2}\right), 4.21\left(\mathrm{t}, J=6.5 \mathrm{~Hz}, 4 \mathrm{H}, \mathrm{OCH}_{2}\right), 7.12$ (s, 4H, ArH), 8.22 (bs, OH). MS (ES+): m/z 451 $(\mathrm{M}+\mathrm{H})^{+}$. Anal. $\mathrm{C}_{22} \mathrm{H}_{26} \mathrm{O}_{10}(\mathrm{C}, \mathrm{H}, \mathrm{N}, \mathrm{O})$.

\section{Dodecamethylene-1,12-diyl-bis-(3,4,5-trihydroxybenzoate) (11)}

Characterization of this compound in the literature was incomplete and NMR was registered in $\mathrm{CDCl}_{3}[22 \mathrm{~b}]$ and $\mathrm{DMSO}$ [22a]. Missing data (melting point) and NMR in acetone were now included.

In a procedure analogous to that described for compound $\mathbf{8}$, gallic acid $\mathbf{1}$ (3.0 mmol, $510 \mathrm{mg}$ ), and 1,12-dodecanediol (1.0 mmol, $202.3 \mathrm{mg})$ afforded $264 \mathrm{mg}(52 \%)$ of 11 as a white solid; m.p. 190-192 ${ }^{\circ} \mathrm{C} .{ }^{1} \mathrm{H}-\mathrm{NMR}\left[\left(\mathrm{CD}_{3}\right)_{2} \mathrm{CO}, 300 \mathrm{MHz}\right] \delta 1.40$ (m, 16H, $\mathrm{CH}_{2}$ ), $1.74\left(\mathrm{~m}, 4 \mathrm{H}, \mathrm{CH}_{2}\right), 4.21$ (t, $\left.J=6.5 \mathrm{~Hz}, 4 \mathrm{H}, \mathrm{OCH}_{2}\right), 7.12$ (s, 4H, ArH), 8.21 (bs, OH). MS (ES+): m/z 507 $(\mathrm{M}+\mathrm{H})^{+}, 529(\mathrm{M}+\mathrm{Na})^{+}$. Anal. $\mathrm{C}_{26} \mathrm{H}_{34} \mathrm{O}_{10}(\mathrm{C}, \mathrm{H}, \mathrm{N}, \mathrm{O})$.

\section{General procedure for the synthesis of alkyl amides 18-22, 24, 26 and 30}

3,4,5-Trimethoxybenzoyl chloride 12 (3 eq) and potassium carbonate (3 eq) were dissolved in a mixture of ethyl acetate/water (1:1) and treated with the corresponding amine (1 eqv). The resulting biphasic solution was stirred overnight and a white precipitate appeared. The solid (OMe protected derivative) was filtered and the filtrate was dried and subsequently dissolved in dry dichloromethane. The resulting solution was cooled by a water-ice bath $\left(0-5^{\circ} \mathrm{C}\right)$ and treated, under argon atmosphere, with boron tribromide (1.5 eq for each OMe group). The reaction was left to reach room temperature and stirred overnight. The precipitate that appeared was filtered and washed repeatedly with gently quantities of cold dichloromethane and ether to give the corresponding unprotected derivative as a white solid. Eventually some products had to be purified by reversed phase SPE cartridges using water/methanol $(20: 1 \rightarrow 1: 1)$ as the eluent.

\section{N,N'-Tetramethylenebis(3,4,5-trihydroxybenzamide) (18)}

1,4-Tetramethylenediamine (75 mg, $0.88 \mathrm{mmol})$, potassium carbonate $(364.87 \mathrm{mg}, 2.64 \mathrm{mmol})$ and 3,4,5trimethoxybenzoyl chloride (12) (609 $\mathrm{mg}, 2.64 \mathrm{mmol})$ reacted according to the general procedure to give $380 \mathrm{mg}(91 \%)$ of the OMe protected derivative 13 as a white solid; m.p. 243-244 ${ }^{\circ} \mathrm{C} .{ }^{1} \mathrm{H}-\mathrm{NMR}$ [ $\left.\left(\mathrm{CD}_{3}\right)_{2} \mathrm{SO}, 300 \mathrm{MHz}\right] \delta 1.55\left(\mathrm{~m}, 4 \mathrm{H}, \mathrm{CH}_{2}\right)$, $3.67\left(\mathrm{~m}, 4 \mathrm{H}, \mathrm{CH}_{2} \mathrm{NH}\right), 3.80\left(\mathrm{~s}, 18 \mathrm{H}, \mathrm{OCH}_{3}\right), 7.1(\mathrm{~s}, 4 \mathrm{H}, \mathrm{ArH}), 8.42(\mathrm{t}, J=5.5 \mathrm{~Hz}, 2 \mathrm{H}, \mathrm{NH}) . \mathrm{MS}(\mathrm{ES}+): \mathrm{m} / \mathrm{z} 477.0(\mathrm{M}+\mathrm{H})^{+}$, $499(\mathrm{M}+\mathrm{Na})^{+}$. Anal. $\mathrm{C}_{24} \mathrm{H}_{32} \mathrm{~N}_{2} \mathrm{O}_{8}(\mathrm{C}, \mathrm{H}, \mathrm{N}, \mathrm{O})$.

Compound 13 (200 mg, $0.21 \mathrm{mmol})$ was treated with boron tribromide $(0.12 \mathrm{~mL})$ obtaining $62.3 \mathrm{mg}(76 \%)$ of 18 as a white solid; m.p. $238-240{ }^{\circ} \mathrm{C} .{ }^{1} \mathrm{H}-\mathrm{NMR}\left[\left(\mathrm{CD}_{3}\right)_{2} \mathrm{SO}, 300 \mathrm{MHz}\right] \delta 1.46\left(\mathrm{bs}, 4 \mathrm{H}, \mathrm{CH}_{2}\right), 3.16\left(\mathrm{bs}, 4 \mathrm{H}, \mathrm{CH} \mathrm{NH}_{2}\right), 6.80(\mathrm{~s}, 4 \mathrm{H}$, ArH), 8.05 (wide s, $2 \mathrm{H}, \mathrm{NH}$ ); 8.83 (bs, 6H, OH). MS (ES+): m/z $393(\mathrm{M}+\mathrm{H})^{+}$. Anal. $\mathrm{C}_{18} \mathrm{H}_{20} \mathrm{~N}_{2} \mathrm{O}_{8}(\mathrm{C}, \mathrm{H}, \mathrm{N}, \mathrm{O})$. 
1,6-Hexamethylenediamine (75 mg, $0.64 \mathrm{mmol}$ ), potassium carbonate (266.74 mg, 1,93 mmol) and 3,4,5trimethoxybenzoyl chloride (12) (445 mg, $1.93 \mathrm{mmol}$ ) reacted according to the general procedure to give $314 \mathrm{mg}(98 \%)$ of the OMe protected derivative 14 as a white solid; m.p. 219-221 ${ }^{\circ} \mathrm{C} .{ }^{1} \mathrm{H}-\mathrm{NMR}\left(\mathrm{CDCl}_{3}, 300 \mathrm{MHz}\right) \delta 1.45\left(\mathrm{~m}, 4 \mathrm{H}, \mathrm{CH}_{2}\right), 1.64$ $\left(\mathrm{m}, 4 \mathrm{H}, \mathrm{CH}_{2}\right), 3.45\left(\mathrm{c}, J=6.7 \mathrm{~Hz}, J=6.2 \mathrm{~Hz}, 4 \mathrm{H}, \mathrm{CH}_{2} \mathrm{NH}\right), 3.87\left(\mathrm{~s}, 6 \mathrm{H}, \mathrm{OCH}_{3}\right), 3.90\left(\mathrm{~s}, 12 \mathrm{H}, \mathrm{OCH}_{3}\right), 6.13(\mathrm{t}, J=5.5 \mathrm{~Hz}$, 2H, NH), 6.99 (s, 4H, ArH). MS (ES+): m/z $505.3(\mathrm{M}+\mathrm{H})^{+}$. Anal. $\mathrm{C}_{26} \mathrm{H}_{36} \mathrm{~N}_{2} \mathrm{O}_{8}(\mathrm{C}, \mathrm{H}, \mathrm{N}, \mathrm{O})$.

Compound $14(200 \mathrm{mg}, 0.40 \mathrm{mmol})$ was treated with boron tribromide $(0.28 \mathrm{~mL})$ obtaining $45.2 \mathrm{mg}(51 \%)$ of 19 as a white solid. Melting point and spectroscopic characterization of compound 19 were consistent with those found in the literature [38].

\section{$N, N^{\prime}$-Octamethylenebis(3,4,5-trihydroxybenzamide) (20)}

1,8-Octamethylenediamine (100 mg, $1.13 \mathrm{mmol}$ ), potassium carbonate (468.5 mg, $3.39 \mathrm{mmol})$ and 3,4,5trimethoxybenzoyl chloride (12) $(780 \mathrm{mg}, 3.39 \mathrm{mmol})$ reacted according to the general procedure to obtain $464 \mathrm{mg}(77 \%)$ of the OMe protected derivative 15 as a white solid; m.p. 201-202 ${ }^{\circ} \mathrm{C} .{ }^{1} \mathrm{H}-\mathrm{NMR}\left(\mathrm{CDCl}_{3}, 300 \mathrm{MHz}\right) \delta 1.37\left(\mathrm{~m}, 8 \mathrm{H}, \mathrm{CH}_{2}\right)$, $1.63\left(\mathrm{~m}, 4 \mathrm{H}, \mathrm{CH}_{2}\right), 3.43\left(\mathrm{c}, \mathrm{J}=6.9 \mathrm{~Hz}, \mathrm{~J}=6.5 \mathrm{~Hz}, 4 \mathrm{H}, \mathrm{CH}_{2} \mathrm{NH}\right), 3.87\left(\mathrm{~s}, 18 \mathrm{H}, \mathrm{OCH}_{3}\right), 6.43(\mathrm{t}, J=5.1 \mathrm{~Hz}, 2 \mathrm{H}, \mathrm{NH}), 7.06$ (s, 4H, ArH). MS (ES+): m/z $533(\mathrm{M}+\mathrm{H})^{+}$. Anal. $\mathrm{C}_{28} \mathrm{H}_{40} \mathrm{~N}_{2} \mathrm{O}_{8}(\mathrm{C}, \mathrm{H}, \mathrm{N}, \mathrm{O})$.

Compound 15 (77 mg, $0.14 \mathrm{mmol})$ was treated with boron tribromide $(0.08 \mathrm{~mL})$ obtaining $54.3 \mathrm{mg}(84 \%)$ of 20 as a white solid; m.p.155-157 ${ }^{\circ} \mathrm{C} .{ }^{1} \mathrm{H}-\mathrm{NMR}\left(\mathrm{CD}_{3} \mathrm{OD}, 300 \mathrm{MHz}\right) \delta 1.38$ (bs, 8H, $\left.\mathrm{CH}_{2}\right), 1.58\left(\mathrm{~m}, 4 \mathrm{H}, \mathrm{CH}_{2}\right), 3.34(\mathrm{~m}, 4 \mathrm{H}$, $\left.\mathrm{CH}_{2} \mathrm{NH}\right), 6.82$ (s, 4H, HAr), MS (ES+): m/z $449(\mathrm{M}+\mathrm{H})^{+}$. Anal. $\mathrm{C}_{22} \mathrm{H}_{28} \mathrm{~N}_{2} \mathrm{O}_{8}(\mathrm{C}, \mathrm{H}, \mathrm{N}, \mathrm{O})$.

\section{N,N'-Decamethylenebis(3,4,5-trihydroxybenzamide) (21)}

1,10-Decamethylenediamine (100 mg, $0.58 \mathrm{mmol})$, potassium carbonate (240.5 $\mathrm{mg}, 1.74 \mathrm{mmol})$ and 3,4,5trimethoxybenzoyl chloride $(402 \mathrm{mg}, 1.74 \mathrm{mmol})$ reacted according to the general procedure to obtain $179 \mathrm{mg}(65 \%)$ of the OMe protected derivative 16 as an amorphous white solid; ${ }^{1} \mathrm{H}-\mathrm{NMR}\left[\mathrm{CDCl}_{3}, 300 \mathrm{MHz}\right] \delta 1.29\left(\mathrm{~m}, 12 \mathrm{H}, \mathrm{CH}_{2}\right), 1.56$ (m, 4H, $\left.\mathrm{CH}_{2}\right), 3.30$ (m, 4H, CH $\left.\mathrm{H}_{2} \mathrm{NH}\right), 3.83$ (s, 18H, $\left.\mathrm{OCH}_{3}\right), 7.17$ (s, 4H, ArH), 8.03 (bs, 2H, NH). MS (ES+): m/z 561 $(\mathrm{M}+\mathrm{H})^{+}$. Anal. $\mathrm{C}_{30} \mathrm{H}_{44} \mathrm{~N}_{2} \mathrm{O}_{8}(\mathrm{C}, \mathrm{H}, \mathrm{N}, \mathrm{O})$.

Compound $16(100 \mathrm{mg}, 0.18 \mathrm{mmol})$ was treated with boron tribromide $(0.102 \mathrm{~mL})$ obtaining $60.1 \mathrm{mg}(70 \%)$ of 21 as a white solid; m.p. $126-128{ }^{\circ} \mathrm{C} .{ }^{1} \mathrm{H}-\mathrm{NMR}\left[\mathrm{CD}_{3} \mathrm{OD}, 300 \mathrm{MHz}\right] \delta 1.24-1.35\left(\mathrm{~m}, 12 \mathrm{H}, \mathrm{CH}_{2}\right), 1.49-1.62\left(\mathrm{~m}, 4 \mathrm{H}, \mathrm{CH}_{2}\right), 3.22-$ $3.32\left(\mathrm{~m}, 4 \mathrm{H}, \mathrm{CH}_{2} \mathrm{NH}\right.$, overlaps with $\left.\mathrm{CD}_{3} \mathrm{OD}\right), 6.83$ (s, 2H, ArH). ${ }^{13} \mathrm{C}-\mathrm{NMR}\left[\mathrm{CD}_{3} \mathrm{OD}, 75 \mathrm{MHz}\right] \delta 28.55\left(\mathrm{CH}_{2}\right), 30.08$ $\left(\mathrm{CH}_{2}\right), 30.99\left(\mathrm{CH}_{2}\right), 32.90\left(\mathrm{CH}_{2}\right), 41.35\left(\mathrm{CH}_{2}\right), 108.14(\mathrm{ArC}), 108.96(\mathrm{ArCH}), 126.71(\mathrm{ArC}), 146.88(\mathrm{ArC}), 173.57(\mathrm{C}=\mathrm{O})$. MS (ES+): m/z $477.5(\mathrm{M}+\mathrm{H})^{+}$. Anal. $\mathrm{C}_{24} \mathrm{H}_{32} \mathrm{~N}_{2} \mathrm{O}_{8}(\mathrm{C}, \mathrm{H}, \mathrm{N}, \mathrm{O})$.

\section{$N, N$ '-Dodecamethylenebis(3,4,5-trihydroxybenzamide) (22)}

1,12-Dodecamethylenediamine (100 $\mathrm{mg}, 0.50 \mathrm{mmol})$, potassium carbonate $(207.3 \mathrm{mg}, 1.50 \mathrm{mmol})$ and 3,4,5trimethoxybenzoyl chloride $(345 \mathrm{mg}, 1.50 \mathrm{mmol})$ reacted according to the general procedure to obtain $206 \mathrm{mg}(70 \%)$ of the OMe protected derivative $\mathbf{1 7}$ as an amorphous white solid; ${ }^{1} \mathrm{H}-\mathrm{NMR}\left[\mathrm{CDCl}_{3}, 300 \mathrm{MHz}\right] \delta 1.29\left(\mathrm{~m}, 16 \mathrm{H}, \mathrm{CH}_{2}\right), 1.55$ 
(m, 4H, $\left.\mathrm{CH}_{2}\right), 3.28\left(\mathrm{~m}, 4 \mathrm{H}, \mathrm{CH}_{2} \mathrm{NH}\right), 3.83$ (s, 18H, $\left.\mathrm{OCH}_{3}\right), 7.18$ (s, 4H, ArH), 8.00 (bs, 2H, NH). MS (ES+): m/z 589 $(\mathrm{M}+\mathrm{H})^{+}$. Anal. $\mathrm{C}_{32} \mathrm{H}_{48} \mathrm{~N}_{2} \mathrm{O}_{8}(\mathrm{C}, \mathrm{H}, \mathrm{N}, \mathrm{O})$.

Compound $17(100 \mathrm{mg}, 0.17 \mathrm{mmol})$ was treated with boron tribromide $(0.097 \mathrm{~mL})$ obtaining $62.5 \mathrm{mg}(70 \%)$ of 22 as a white solid. Characterization of this compound in the literature [22b] was incomplete and NMR was made in DMSO- $d_{6}$. Missing data (melting point) and NMR in acetone were now included; m.p. $135-137{ }^{\circ} \mathrm{C} .{ }^{1} \mathrm{H}-\mathrm{RMN}\left[\left(\mathrm{CD}_{3}\right)_{2} \mathrm{SO}, 300 \mathrm{MHz}\right] \delta$ $1.24\left(\mathrm{~m}, 16 \mathrm{H}, \mathrm{CH}_{2}\right), 1.45\left(\mathrm{~m}, 4 \mathrm{H}, \mathrm{CH}_{2}\right), 3.16\left(\mathrm{~m}, 4 \mathrm{H}, \mathrm{CH}_{2} \mathrm{NH}\right), 6.80(\mathrm{~s}, 4 \mathrm{H}, \mathrm{ArH}), 8.00(\mathrm{t}, J=5.5 \mathrm{~Hz}, 2 \mathrm{H}, \mathrm{NH}), 8.25(\mathrm{bs}$, OH). MS (ES+): m/z $505(\mathrm{M}+\mathrm{H})^{+}$. Anal. $\mathrm{C}_{26} \mathrm{H}_{36} \mathrm{~N}_{2} \mathrm{O}_{8}(\mathrm{C}, \mathrm{H}, \mathrm{N}, \mathrm{O})$.

$N, N$, $N$ ''-Tris-(3,4,5-trihydroxybenzoyl)diethylenetriamine (24)

Diethylenetriamine $(100 \mathrm{mg}, 0.96 \mathrm{mmol})$, potassium carbonate $(531 \mathrm{mg}, 3.84 \mathrm{mmol})$ and 3,4,5-trimethoxybenzoyl chloride (12) (708 mg, $3.07 \mathrm{mmol}$ ) reacted according to the general procedure to give $241 \mathrm{mg}(38 \%)$ of the OMe protected derivative 23 as a white solid; m.p. 96-99 ${ }^{\circ} \mathrm{C} .{ }^{1} \mathrm{H}-\mathrm{NMR}\left[\left(\mathrm{CD}_{3}\right)_{2} \mathrm{CO}, 300 \mathrm{MHz}\right] \delta 3.21\left(\mathrm{~m}, 8 \mathrm{H}, \mathrm{CH}_{2} \mathrm{NH}\right), 3.57-3.81(\mathrm{~m}, 27 \mathrm{H}$, $\mathrm{OCH}_{3}$ ), 6.5 (bs, 2H, ArH), 7.20 (wide s, 4H, ArH), 8.21 (wide s, 2H, NH). MS (ES+): m/z $686(\mathrm{M}+\mathrm{H})^{+}$. Anal. $\mathrm{C}_{34} \mathrm{H}_{43} \mathrm{~N}_{3} \mathrm{O}_{12}(\mathrm{C}, \mathrm{H}, \mathrm{N}, \mathrm{O})$.

Compound 23 (548 mg, $0.8 \mathrm{mmol})$ was treated with boron tribromide $(0.70 \mathrm{~mL})$ obtaining $130.5 \mathrm{mg}(30 \%)$ of 24 as an amorphous white solid. ${ }^{1} \mathrm{H}-\mathrm{NMR}\left[\mathrm{D}_{2} \mathrm{O}, 300 \mathrm{MHz}\right] \delta 3.16-3.54\left(\mathrm{~m}, 8 \mathrm{H}, \mathrm{CH}_{2} \mathrm{NH}\right), 6.01$ (bs, 2H, NH), $6.52(\mathrm{bs}, 3 \mathrm{H}, \mathrm{ArH}$ 6.62 (bs, 3H, ArH). MS (ES+): m/z $560(\mathrm{M}+\mathrm{H})^{+}$. Anal. $\mathrm{C}_{25} \mathrm{H}_{25} \mathrm{~N}_{3} \mathrm{O}_{12}(\mathrm{C}, \mathrm{H}, \mathrm{N}, \mathrm{O})$.

$N, N^{\prime}, N$ ',-Tris(3,4,5-trihydroxybenzoyl) spermidine (26)

Spermidine (50 mg, $0.34 \mathrm{mmol})$, potassium carbonate $(188 \mathrm{mg}, 1.36 \mathrm{mmol})$ and 3,4,5-trimethoxybenzoyl chloride (12) (313 $\mathrm{mg}, 1.36 \mathrm{mmol}$ ) reacted according to the general procedure to give $96.3 \mathrm{mg}$ (39\%) of the OMe protected derivative 25 as a white solid; m.p. $78-80^{\circ} \mathrm{C} .{ }^{1} \mathrm{H}-\mathrm{NMR}\left[\left(\mathrm{CD}_{3}\right)_{2} \mathrm{CO}, 300 \mathrm{MHz}\right] \delta 1.52\left(\mathrm{~m}, 4 \mathrm{H}, \mathrm{CH}_{2}\right), 1.73\left(\mathrm{~m}, 2 \mathrm{H}, \mathrm{CH}_{2}-\mathrm{CH}_{2}-\mathrm{NH}\right), 3.43$ $\left(\mathrm{m}, 8 \mathrm{H}, \mathrm{CH}_{2} \mathrm{NH}\right), 3.82\left(\mathrm{~s}, 9 \mathrm{H}, \mathrm{OCH}_{3}\right), 3.83\left(\mathrm{~s}, 9 \mathrm{H}, \mathrm{OCH}_{3}\right), 3.84\left(\mathrm{~s}, 9 \mathrm{H}, \mathrm{OCH}_{3}\right), 7.23$ (bs, 6H, H-Ar). MS (ES+): m/z 728 $(\mathrm{M}+\mathrm{H})^{+}$. Anal. $\mathrm{C}_{37} \mathrm{H}_{49} \mathrm{~N}_{3} \mathrm{O}_{12}(\mathrm{C}, \mathrm{H}, \mathrm{N}, \mathrm{O})$.

Compound $25(72.7 \mathrm{mg}, 0.1 \mathrm{mmol})$ was treated with boron tribromide $(0.085 \mathrm{~mL})$ obtaining $56.7 \mathrm{mg}(95 \%)$ of 26 as a white solid. ${ }^{1} \mathrm{H}-\mathrm{NMR}\left(\mathrm{CD}_{3} \mathrm{OD}, 300 \mathrm{MHz}\right) \delta 1.76\left(\mathrm{~m}, 6 \mathrm{H}, \mathrm{CH}_{2}\right), 2.99(\mathrm{~m}, 8 \mathrm{H}, \mathrm{CH}-\mathrm{NH}), 6.41$ (bs, 3H, ArH), 6.85 (wide s, $3 \mathrm{H}, \mathrm{ArH})$. MS (ES+): m/z $602(\mathrm{M}+\mathrm{H})^{+}$. Anal. $\mathrm{C}_{28} \mathrm{H}_{31} \mathrm{~N}_{3} \mathrm{O}_{12}(\mathrm{C}, \mathrm{H}, \mathrm{N}, \mathrm{O})$.

\section{Tris [2-(3',4',5'-trihydroxybenzamido)ethyl]amine (28)}

Tris(2-aminoethyl)amine (50 mg, $0.34 \mathrm{mmol})$, potassium carbonate $(188 \mathrm{mg}, 1.36 \mathrm{mmol})$ and 3,4,5-trimethoxybenzoyl chloride (12) (313 mg, $1.36 \mathrm{mmol})$ reacted according to the general procedure to give $171.8 \mathrm{mg}(72 \%)$ of the $\mathrm{OMe}$ protected derivative $\mathbf{2 7}$ as a white solid. Characterization of this compound in the literature was incomplete [29] and NMR was made in $\mathrm{CDCl}_{3}$. Missing data (melting point) and NMR in acetone were now included; m.p. $150-152{ }^{\circ} \mathrm{C} .{ }^{1} \mathrm{H}-\mathrm{NMR}$ $\left[\left(\mathrm{CD}_{3}\right)_{2} \mathrm{CO}, 300 \mathrm{MHz}\right] \delta 2.77\left(\mathrm{t}, J=5.6 \mathrm{~Hz}, 6 \mathrm{H}, \mathrm{CH}_{2} \mathrm{~N}\right), 3.52\left(\mathrm{~m}, 6 \mathrm{H}, \mathrm{CH}_{2} \mathrm{NH}\right), 3.72\left(\mathrm{~s}, 9 \mathrm{H}, \mathrm{OCH}_{3}\right), 3.76\left(\mathrm{~s}, 18 \mathrm{H}, \mathrm{OCH}_{3}\right)$, 7.17 (s, 6H, ArH), 7.98 (t, J=5.1 Hz, 3H, NH). MS (ES+): m/z $729(\mathrm{M}+\mathrm{H})^{+}$. Anal. $\mathrm{C}_{36} \mathrm{H}_{48} \mathrm{~N}_{4} \mathrm{O}_{12}(\mathrm{C}, \mathrm{H}, \mathrm{N}, \mathrm{O})$. 
Compound 27 (107 mg, $0.15 \mathrm{mmol})$ was treated with boron tribromide $(0.13 \mathrm{~mL})$ obtaining $82 \mathrm{mg}(93 \%)$ of 28 as a white solid. Melting point and spectroscopic characterization of compound $\mathbf{2 8}$ were consistent with those found in the literature [29].

$N, N$, $N$ ', $N$,',,$N$,','-Pentakis(3,4,5-trihydroxybenzoyl)tetraethylenepentamine (30)

Tetraethylenepentamine $(50 \mathrm{mg}, 0.26 \mathrm{mmol})$ potassium carbonate $(215.6 \mathrm{mg}, 1.56 \mathrm{mmol})$ and 3,4,5-trimethoxybenzoyl chloride (12) (359 mg, $1.56 \mathrm{mmol}$ ) reacted according to the general procedure to give $153.3 \mathrm{mg}(85 \%)$ of the OMe protected derivative 29 as a white solid; m.p. 102-105 ${ }^{\circ} \mathrm{C} .{ }^{1} \mathrm{H}-\mathrm{NMR}$ [ $\left.\left(\mathrm{CD}_{3}\right)_{2} \mathrm{CO}, 300 \mathrm{MHz}\right] \delta 3.4-3.9\left(\mathrm{~m}, 61 \mathrm{H}, \mathrm{CH}_{2}, \mathrm{OCH}_{3}\right)$, 6.33-7.09 (m, 10H, ArH). MS (ES+): m/z $1161(\mathrm{M}+\mathrm{H})^{+}$. Anal. $\mathrm{C}_{58} \mathrm{H}_{73} \mathrm{~N}_{5} \mathrm{O}_{20}(\mathrm{C}, \mathrm{H}, \mathrm{N}, \mathrm{O})$.

Compound $29(105 \mathrm{mg}, 0.09 \mathrm{mmol})$ was treated with boron tribromide $(0.13 \mathrm{~mL})$ obtaining 30 quantitatively as a white solid; m.p. $175-177{ }^{\circ} \mathrm{C} .{ }^{1} \mathrm{H}-\mathrm{NMR}\left(\mathrm{CD}_{3} \mathrm{OD}, 300 \mathrm{MHz}\right) \delta 3.21-3.76\left(\mathrm{~m}, 16 \mathrm{H}, \mathrm{CH}_{2}\right), 7.02-7.33$ (m, 10H, ArH). MS $(\mathrm{ES}+): \mathrm{m} / \mathrm{z} 950(\mathrm{M}+\mathrm{H})^{+}$. Anal. $\mathrm{C}_{43} \mathrm{H}_{43} \mathrm{~N}_{5} \mathrm{O}_{20}(\mathrm{C}, \mathrm{H}, \mathrm{N}, \mathrm{O})$.

\section{General Method for the synthesis of alkyl amides 37-41, 43 and 45}

Benzotriazol-1-yl-oxytripyrrolidinophosphonium hexafluorophosphate (pyBOP) (1.1 mmol for each NH moiety) was added to a solution of 2,3,4-tribenzyloxybenzoic acid $\mathbf{3 1}$ (1.1 mmol for each NH moiety) in dry dichloromethane (20 mL). After $5 \mathrm{~min}$, triethylamine (TEA) (1 mmol for each NH moiety) and the corresponding amine (1 mmol) were added. The mixture was stirred at room temperature overnight and then evaporated to dryness. The residue was dissolved in ethyl acetate $(30 \mathrm{~mL})$ and washed successively with saturated solutions of citric acid $(3 \times 20 \mathrm{~mL}), \mathrm{NaHCO}_{3}(3 \times 20 \mathrm{~mL})$ and $\mathrm{NaCl}(1 \times 20 \mathrm{~mL})$. The residue was concentrated and purified by column chromatography using hexane/ethyl acetate (5:1).

A solution of the corresponding OBn protected derivative in THF/MeOH (1:1) containing $30 \mathrm{wt} \%$ of $\mathrm{Pd} / \mathrm{C}(10 \%)$ was hydrogenated at $30{ }^{\circ} \mathrm{C}$ overnight under atmospheric pressure using a reaction balloon filled with hydrogen gas and a glass flask as the reaction vessel. The $\mathrm{Pd} / \mathrm{C}$ was filtered through Whatman ${ }^{\circledR}$ filter paper 42 and the solvent was removed under reduced pressure to give the crude product which was then purified by triturating with diethyl ether or dichloromethane to afford the corresponding deprotected derivative.

N,N'-Tetramethylenebis(2,3,4-hydroxybenzamide) (37)

According to the general procedure 1,4-tetramethylenediamine $(35.2 \mathrm{mg}, 0.40 \mathrm{mmol})$ was treated with 2,3,4tribenzyloxybenzoic acid 31 (440 mg, $1.00 \mathrm{mmol})$ to give $373 \mathrm{mg}(100 \%)$ of the $\mathrm{OBn}$ protected derivative 32 as a white solid; m.p. $145-147^{\circ} \mathrm{C} .{ }^{1} \mathrm{H}-\mathrm{NMR}\left[\mathrm{CDCl}_{3}, 300 \mathrm{MHz}\right] \delta 1.18-1.25\left(\mathrm{~m}, 4 \mathrm{H}, \mathrm{CH}_{2}\right), 3.15-3.20\left(\mathrm{~m}, 4 \mathrm{H}, \mathrm{CH}_{2} \mathrm{NH}\right), 5.07(\mathrm{~s}, 4 \mathrm{H}$, $\left.\mathrm{CH}_{2} \mathrm{Ph}\right), 5.11\left(\mathrm{~s}, 4 \mathrm{H}, \mathrm{CH}_{2} \mathrm{Ph}\right), 5.17\left(\mathrm{~s}, 4 \mathrm{H}, \mathrm{CH}_{2} \mathrm{Ph}\right), 6.89$ (d, 2H, J=9.6 Hz, ArH), 7.30-7.50 (m, 30H, ArH), 7.92 (d, $2 \mathrm{H}, J$ $=9.6 \mathrm{~Hz}, \mathrm{ArH})$. Anal. $\mathrm{C}_{60} \mathrm{H}_{56} \mathrm{~N}_{2} \mathrm{O}_{8}(\mathrm{C}, \mathrm{H}, \mathrm{N}, \mathrm{O})$.

Following the deprotection procedure, the $\mathrm{OBn}$ derivative $32(100 \mathrm{mg}, 0.107 \mathrm{mmol})$ gave a crude product which was then purified by triturating with diethyl ether to afford $19.1 \mathrm{mg}(46 \%)$ of 37 as a pale yellow solid; m.p. $225-227^{\circ} \mathrm{C} .{ }^{1} \mathrm{H}-$ NMR [CD $\left.{ }_{3} \mathrm{OD}, 300 \mathrm{MHz}\right] \delta$ 1.60-1.78 (m, 4H, $\left.\mathrm{CH}_{2}\right), 3.35-3.50\left(\mathrm{~m}, 4 \mathrm{H}, \mathrm{CH}_{2} \mathrm{NH}\right), 6.34(\mathrm{~d}, 2 \mathrm{H}, J=9.2 \mathrm{~Hz}, \mathrm{ArH}), 7.12(\mathrm{~d}$, $2 \mathrm{H}, J=9.2 \mathrm{~Hz}, \mathrm{ArH}) .{ }^{13} \mathrm{C}-\mathrm{NMR}\left[\mathrm{CD}_{3} \mathrm{OD}, 75 \mathrm{MHz}\right] \delta 26.57\left(\mathrm{CH}_{2}\right), 38.56\left(\mathrm{CH}_{2}\right), 106.37$ (ArC), $107.47(\operatorname{ArC}), 117.63$ 
(ArC), 132.56 (ArC), $149.21(\mathrm{ArC}), 150.22(\mathrm{ArC}), 170.47(\mathrm{C}=\mathrm{O}) . \mathrm{MS}(\mathrm{ES}+): \mathrm{m} / \mathrm{z} 393.3(\mathrm{M}+\mathrm{H})^{+}$. MS (ES+): m/z 393 $(\mathrm{M}+\mathrm{H})^{+}$. Anal. $\mathrm{C}_{18} \mathrm{H}_{20} \mathrm{~N}_{2} \mathrm{O}_{8}(\mathrm{C}, \mathrm{H}, \mathrm{N}, \mathrm{O})$.

\section{$N, N$ '-Hexamethylenebis(2,3,4-hydroxybenzamide) (38)}

According to the general procedure 1,6-hexamethylenediamine $(23,3 \mathrm{mg}, 0.20 \mathrm{mmol})$ was treated with 2,3,4tribenzyloxybenzoic acid $31(220 \mathrm{mg}, 0.50 \mathrm{mmol})$ to give $131.3 \mathrm{mg}(69 \%)$ of the $\mathrm{OBn}$ protected derivative 33 as a white solid; m.p. 134-135 ${ }^{\circ} \mathrm{C} .{ }^{1} \mathrm{H}-\mathrm{NMR}\left[\mathrm{CDCl}_{3}, 300 \mathrm{MHz}\right] \delta$ 1.05-1.17 (m, 4H, $\left.\mathrm{CH}_{2}\right), 1.17-1.32\left(\mathrm{~m}, 4 \mathrm{H}, \mathrm{CH}_{2}\right), 3.16-3.27(\mathrm{~m}, 4 \mathrm{H}$, $\left.\mathrm{CH}_{2} \mathrm{NH}\right), 5.08\left(\mathrm{~s}, 4 \mathrm{H}, \mathrm{CH}_{2} \mathrm{Ph}\right), 5.13\left(\mathrm{~s}, 4 \mathrm{H}, \mathrm{CH}_{2} \mathrm{Ph}\right), 5.16\left(\mathrm{~s}, 4 \mathrm{H}, \mathrm{CH}_{2} \mathrm{Ph}\right), 6.88(\mathrm{~d}, 2 \mathrm{H}, J=9.3 \mathrm{~Hz}, \mathrm{ArH}), 7.28-7.51(\mathrm{~m}$, $30 \mathrm{H}, \mathrm{ArH}), 7.92(\mathrm{~d}, 2 \mathrm{H}, J=9.3 \mathrm{~Hz}, \mathrm{ArH}) .{ }^{13} \mathrm{C}-\mathrm{NMR}\left[\mathrm{CDCl}_{3}, 75 \mathrm{MHz}\right] \delta 26.99\left(\mathrm{CH}_{2}\right), 29.49\left(\mathrm{CH}_{2}\right), 39.95\left(\mathrm{CH}_{2}\right), 71.46$ $\left(\mathrm{CH}_{2} \mathrm{Ph}\right), 76.06\left(\mathrm{CH}_{2} \mathrm{Ph}\right), 109.73(\mathrm{ArCH}), 120.12(\mathrm{ArC}), 127.99(\mathrm{ArCH}), 128.62(\mathrm{ArCH}), 128.82(\mathrm{ArCH}), 129.06(\mathrm{ArCH})$, 129.08 (ArCH), 129.16 (ArCH), 132.46 (ArC), 133.57 (ArC), 136.67 (ArC), 136.73 (ArC), 137.57 (ArC), 141.61 (ArC), 152.07 (ArC), 156.05 (ArC), $165.15(\mathrm{C}=\mathrm{O})$. Anal. $\mathrm{C}_{62} \mathrm{H}_{60} \mathrm{~N}_{2} \mathrm{O}_{8}(\mathrm{C}, \mathrm{H}, \mathrm{N}, \mathrm{O})$.

Following the deprotection procedure, the OBn derivative $33(121.66 \mathrm{mg}, 0.126 \mathrm{mmol})$ gave a crude product which was then purified by triturating with diethyl ether to give $22 \mathrm{mg}(42 \%)$ of 38 as a pale yellow solid; m.p. $163-165{ }^{\circ} \mathrm{C}$. ${ }^{1} \mathrm{H}-$ NMR $\left[\mathrm{CD}_{3} \mathrm{OD}, 300 \mathrm{MHz}\right] \delta$ 1.40-1.49 (m, 4H, $\left.\mathrm{CH}_{2}\right), 1.56-1.69\left(\mathrm{~m}, 4 \mathrm{H}, \mathrm{CH}_{2}\right), 3.30-3.40\left(\mathrm{~m}, 4 \mathrm{H}, \mathrm{CH}_{2} \mathrm{NH}\right.$, overlaps with $\left.\mathrm{CD}_{3} \mathrm{OD}\right), 6.35(\mathrm{~d}, 2 \mathrm{H}, J=8.8 \mathrm{~Hz}, \mathrm{ArH}), 7.13(\mathrm{~d}, 2 \mathrm{H}, J=8.8 \mathrm{~Hz}, \mathrm{ArH}) .{ }^{13} \mathrm{C}-\mathrm{NMR}\left[\mathrm{CD}_{3} \mathrm{OD}, 75 \mathrm{MHz}\right] \delta 26.86\left(\mathrm{CH}_{2}\right), 29.45$ $\left(\mathrm{CH}_{2}\right), 39.45\left(\mathrm{CH}_{2}\right), 106.82(\mathrm{ArC}), 107.95(\mathrm{ArCH}), 117.94(\mathrm{ArCH}), 133.02(\mathrm{ArC}), 149.52(\mathrm{ArC}), 150.48(\mathrm{ArC}), 170.74$ $(\mathrm{C}=\mathrm{O})$. MS (ES+): m/z $421.4(\mathrm{M}+\mathrm{H})^{+}$. Anal. $\mathrm{C}_{20} \mathrm{H}_{24} \mathrm{~N}_{2} \mathrm{O}_{8}(\mathrm{C}, \mathrm{H}, \mathrm{N}, \mathrm{O})$.

\section{N,N'-Octamethylenebis(2,3,4-hydroxybenzamide) (39)}

According to the general procedure 1,8-octamethylenediamine $(28.8 \mathrm{mg}, 0.20 \mathrm{mmol})$ was treated with 2,3,4tribenzyloxybenzoic acid $31(220 \mathrm{mg}, 0.50 \mathrm{mmol})$ to give $121.9 \mathrm{mg}(62 \%)$ of the $\mathrm{OBn}$ protected derivative 34 as a white solid; m.p. 122-124 ${ }^{\circ} \mathrm{C} .{ }^{1} \mathrm{H}-\mathrm{NMR}\left[\mathrm{CDCl}_{3}, 300 \mathrm{MHz}\right] \delta$ 1.09-1.23 (m, 8H, $\left.\mathrm{CH}_{2}\right), 1.23-1.35\left(\mathrm{~m}, 4 \mathrm{H}, \mathrm{CH}_{2}\right), 3.19-3.28(\mathrm{~m}, 4 \mathrm{H}$, $\left.\mathrm{CH}_{2} \mathrm{NH}\right), 5.09$ (s, 4H, CH $\left.2 \mathrm{Ph}\right), 5.12\left(\mathrm{~s}, 4 \mathrm{H}, \mathrm{CH}_{2} \mathrm{Ph}\right), 5.17$ (s, 4H, $\left.\mathrm{CH}_{2} \mathrm{Ph}\right), 6.89$ (d, 2H, J = 9.1 Hz, ArH), 7.26-7.49 (m, $30 \mathrm{H}, \mathrm{ArH}), 7.86(\mathrm{bs}, 1 \mathrm{H}, \mathrm{NH}), 7.93(\mathrm{~d}, 2 \mathrm{H}, J=9.1 \mathrm{~Hz}, \mathrm{ArH}) .{ }^{13} \mathrm{C}-\mathrm{NMR}\left[\mathrm{CDCl}_{3}, 75 \mathrm{MHz}\right] \delta 27.56\left(\mathrm{CH}_{2}\right), 29.59\left(\mathrm{CH}_{2}\right)$, $29.72\left(\mathrm{CH}_{2}\right), 39.95\left(\mathrm{CH}_{2}\right), 71.29\left(\mathrm{CH}_{2} \mathrm{Ph}\right), 76.23\left(\mathrm{CH}_{2} \mathrm{Ph}\right), 109.67(\mathrm{ArCH}), 120.35(\mathrm{ArC}), 127.31(\mathrm{ArCH}), 128.00(\mathrm{ArCH})$, $128.61(\mathrm{ArCH}), 128.81(\mathrm{ArCH}), 129.05(\mathrm{ArCH}), 129.09(\mathrm{ArCH}), 129.13(\mathrm{ArCH}), 136.67(\mathrm{ArC}), 136.81(\mathrm{ArC}), 137.55$ (ArC), 141.46 (ArC), 152.17 (ArC), 156.02 (ArC), $165.14(\mathrm{C}=\mathrm{O})$. Anal. $\mathrm{C}_{64} \mathrm{H}_{64} \mathrm{~N}_{2} \mathrm{O}_{8}(\mathrm{C}, \mathrm{H}, \mathrm{N}, \mathrm{O})$.

Following the deprotection procedure, the OBn derivative $34(112.2 \mathrm{mg}, 0.113 \mathrm{mmol})$ gave a crude product which was then purified by triturating with dichloromethane to afford $25 \mathrm{mg}(48 \%)$ of 39 as a white solid; m.p. 179-181 ${ }^{\circ} \mathrm{C}$. ${ }^{1} \mathrm{H}-\mathrm{NMR}$ $\left[\mathrm{CD}_{3} \mathrm{OD}, 300 \mathrm{MHz}\right] \delta$ 1.36-1.44 (m, 8H, $\left.\mathrm{CH}_{2}\right), 1.55-1.67\left(\mathrm{~m}, 4 \mathrm{H}, \mathrm{CH}_{2}\right), 3.27-3.36\left(\mathrm{~m}, 4 \mathrm{H}, \mathrm{CH}_{2} \mathrm{NH}\right.$, overlaps with $\left.\mathrm{CD}_{3} \mathrm{OD}\right), 6.35(\mathrm{~d}, 2 \mathrm{H}, J=8.8 \mathrm{~Hz}, \mathrm{ArH}), 7.12(\mathrm{~d}, 2 \mathrm{H}, J=8.8 \mathrm{~Hz}, \mathrm{ArH}) .{ }^{13} \mathrm{C}-\mathrm{NMR}\left[\mathrm{CD}_{3} \mathrm{OD}, 75 \mathrm{MHz}\right] \delta 27.98\left(\mathrm{CH}_{2}\right), 30.33$ $\left(\mathrm{CH}_{2}\right), 30.50\left(\mathrm{CH}_{2}\right), 40.36\left(\mathrm{CH}_{2}\right), 107.79(\mathrm{ArC}), 108.98(\mathrm{ArCH}), 119.05(\mathrm{ArCH}), 133.57(\mathrm{ArC}), 150.71(\mathrm{ArC}), 151.54$ (ArC), $171.76(\mathrm{C}=\mathrm{O})$. MS (ES+): m/z $449.6(\mathrm{M}+\mathrm{H})^{+}$. Anal. $\mathrm{C}_{22} \mathrm{H}_{28} \mathrm{~N}_{2} \mathrm{O}_{8}(\mathrm{C}, \mathrm{H}, \mathrm{N}, \mathrm{O})$. 
According to the general procedure 1,10-diaminodecane (34.5 $\mathrm{mg}, 0.20 \mathrm{mmol}$ ) was treated with 2,3,4-tribenzyloxybenzoic acid (220 mg, $0.50 \mathrm{mmol})$ to give $97.4 \mathrm{mg}(51 \%)$ of the $\mathrm{OBn}$ protected derivative 35 as a white solid; m.p. $110-112{ }^{\circ} \mathrm{C} .{ }^{1} \mathrm{H}-$ NMR $\left[\mathrm{CDCl}_{3}, 300 \mathrm{MHz}\right] \delta 1.17-1.23\left(\mathrm{~m}, 12 \mathrm{H}, \mathrm{CH}_{2}\right), 1.25-1.35\left(\mathrm{~m}, 4 \mathrm{H}, \mathrm{CH}_{2}\right), 3.21-3.29\left(\mathrm{~m}, 4 \mathrm{H}, \mathrm{CH}_{2} \mathrm{NH}\right), 5.08(\mathrm{~s}, 4 \mathrm{H}$, $\mathrm{CH}_{2} \mathrm{Ph}$ ), 5.13 (s, 4H, CH $\left.\mathrm{H}_{2} \mathrm{Ph}\right), 5.17$ (s, 4H, CH$\left.H_{2} \mathrm{Ph}\right), 6.89$ (d, 2H, J=9.2 Hz, ArH), 7.28-7.48 (m, 30H, ArH), 7.92 (d, $2 \mathrm{H}, J$ $=9.2 \mathrm{~Hz}, \mathrm{ArH}) .{ }^{13} \mathrm{C}-\mathrm{NMR}\left[\mathrm{CDCl}_{3}, 75 \mathrm{MHz}\right] \delta 27.35\left(\mathrm{CH}_{2}\right), 29.72\left(\mathrm{CH}_{2}\right), 29.89\left(\mathrm{CH}_{2}\right), 39.82\left(\mathrm{CH}_{2}\right), 71.30\left(\mathrm{CH}_{2} \mathrm{Ph}\right), 76.01$ $\left(\mathrm{CH}_{2} \mathrm{Ph}\right), 109.60(\mathrm{ArCH}), 120.18(\mathrm{ArC}), 127.30(\mathrm{ArCH}), 127.99(\mathrm{ArCH}), 128.61(\mathrm{ArCH}), 128.81(\mathrm{ArCH}), 129.11(\mathrm{ArCH})$, 136.68 (ArC), 136.75 (ArC), 137.51 (ArC), 141.75 (ArC), 152.22 (ArC), $156.03(\mathrm{ArC}), 165.17\left(\mathrm{C}=\mathrm{O} . \mathrm{Anal} \mathrm{C}_{66} \mathrm{H}_{68} \mathrm{~N}_{2} \mathrm{O}_{8}\right.$ $(\mathrm{C}, \mathrm{H}, \mathrm{N}, \mathrm{O})$.

Following the deprotection procedure, the OBn derivative $35(90 \mathrm{mg}, 0.088 \mathrm{mmol})$ gave a crude product which was then purified by triturating with dichloromethane to afford $25.3 \mathrm{mg}(61 \%)$ of $\mathbf{4 0}$ as a white solid; m.p. $177-179{ }^{\circ} \mathrm{C} .{ }^{1} \mathrm{H}-$

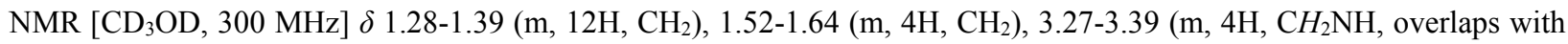
$\left.\mathrm{CD}_{3} \mathrm{OD}\right), 6.35(\mathrm{~d}, 2 \mathrm{H}, J=9.1 \mathrm{~Hz}, \mathrm{ArH}), 7.12(\mathrm{~d}, 2 \mathrm{H}, J=9.1 \mathrm{~Hz}, \mathrm{ArH}) .{ }^{13} \mathrm{C}-\mathrm{NMR}\left[\mathrm{CD}_{3} \mathrm{OD}, 75 \mathrm{MHz}\right] \delta 28.02\left(\mathrm{CH}_{2}\right), 30.35$ $\left(\mathrm{CH}_{2}\right), 30.50\left(\mathrm{CH}_{2}\right), 30.54\left(\mathrm{CH}_{2}\right), 40.36\left(\mathrm{CH}_{2}\right), 107.77$ (ArC), $108.96(\mathrm{ArCH}), 119.03(\mathrm{ArCH}), 133.96(\mathrm{ArC}), 150.57$ (ArC), $151.56(\operatorname{ArC}), 171.74(\mathrm{C}=\mathrm{O})$. MS (ES+): m/z $477.5(\mathrm{M}+\mathrm{H})^{+}$. Anal. $\mathrm{C}_{24} \mathrm{H}_{32} \mathrm{~N}_{2} \mathrm{O}_{8}(\mathrm{C}, \mathrm{H}, \mathrm{N}, \mathrm{O})$.

\section{$N, N$ '-Dodecamethylenebis(2,3,4-hydroxybenzamide) (41)}

According to the general procedure 1,12-dodecamethylendiamine $(80.14 \mathrm{mg}, 0.40 \mathrm{mmol})$ was treated with 2,3,4tribenzyloxybenzoic acid (440 mg, $1 \mathrm{mmol})$ to give $417 \mathrm{mg}(100 \%)$ of the OBn protected derivative $\mathbf{3 6}$ as a white solid; m.p. 92-94 ${ }^{\circ} \mathrm{C} .{ }^{1} \mathrm{H}-\mathrm{NMR}\left[\mathrm{CDCl}_{3}, 300 \mathrm{MHz}\right] \delta$ 0.90-1.00 (m, 4H, $\left.\mathrm{CH}_{2}\right), 1.17-1.40\left(\mathrm{~m}, 16 \mathrm{H}, \mathrm{CH}_{2}\right), 3.20-3.40\left(\mathrm{~m}, 4 \mathrm{H}, \mathrm{CH}_{2}-\right.$ $\mathrm{NH}), 5.07$ (s, 4H, $\left.\mathrm{CH}_{2} \mathrm{Ph}\right), 5.14$ (s, 4H, $\left.\mathrm{CH}_{2} \mathrm{Ph}\right), 5.19$ (s, 4H, $\left.\mathrm{CH}_{2} \mathrm{Ph}\right), 6.80-7.00$ (m, 2H, ArH), 7.28-7.51 (m, 28H, ArH), 7.80-8.00 (m, 4H, ArH). Anal. $\mathrm{C}_{68} \mathrm{H}_{72} \mathrm{~N}_{2} \mathrm{O}_{8}(\mathrm{C}, \mathrm{H}, \mathrm{N}, \mathrm{O})$.

Following the deprotection procedure, the OBn derivative $36(106 \mathrm{mg}, 0.102 \mathrm{mmol})$ gave a crude product which was then purified by triturating with dichloromethane to afford $24 \mathrm{mg}(47 \%)$ of $\mathbf{4 1}$ as a white solid; m.p. $151-153{ }^{\circ} \mathrm{C}$. ${ }^{1} \mathrm{H}-\mathrm{NMR}$ $\left[\mathrm{CD}_{3} \mathrm{OD}, 500 \mathrm{MHz}\right] \delta 1.20-1.47\left(\mathrm{~m}, 16 \mathrm{H}, \mathrm{CH}_{2}\right), 1.52-1.58\left(\mathrm{~m}, 4 \mathrm{H}, \mathrm{CH}_{2}\right), 3.30-3.40\left(\mathrm{~m}, 4 \mathrm{H}, \mathrm{CH} \mathrm{NH}_{2}\right), 6.34(\mathrm{~d}, 2 \mathrm{H}, J=8.8$ $\mathrm{Hz}, \mathrm{ArH}), 7.12(\mathrm{~d}, 2 \mathrm{H}, J=8.8 \mathrm{~Hz}, \mathrm{ArH}) .{ }^{13} \mathrm{C}-\mathrm{NMR}\left[\mathrm{CD}_{3} \mathrm{OD}, 75 \mathrm{MHz}\right] \delta 28.54\left(\mathrm{CH}_{2}\right), 30.89\left(\mathrm{CH}_{2}\right), 31.01\left(\mathrm{CH}_{2}\right), 31.12$ $\left(\mathrm{CH}_{2}\right), 31.14\left(\mathrm{CH}_{2}\right), 40.89\left(\mathrm{CH}_{2}\right), 108.27$ (ArC), 109.47 (ArC), 119.54 (ArC), 134.49 (ArC), 151.08 (ArC), 152.09 (ArC), $172.25(\mathrm{C}=\mathrm{O})$. MS (ES+): m/z $505.3(\mathrm{M}+\mathrm{H})^{+}$. Anal. $\mathrm{C}_{26} \mathrm{H}_{36} \mathrm{~N}_{2} \mathrm{O}_{8}(\mathrm{C}, \mathrm{H}, \mathrm{N}, \mathrm{O})$.

\section{$N, N$, $N$ ',-Tris(2,3,4-trihydroxybenzoyl)spermidine (43)}

According to the general procedure spermidine $(50 \mathrm{mg}, 0.34 \mathrm{mmol})$ was treated with 2,3,4-tribenzyloxybenzoic acid 31 (500 mg, $1.13 \mathrm{mmol})$ to give $240 \mathrm{mg}(75 \%)$ of the $\mathrm{OBn}$ protected derivative 42 as a white solid; m.p. $68-70{ }^{\circ} \mathrm{C} .{ }^{1} \mathrm{H}-\mathrm{NMR}$ $\left[\mathrm{CDCl}_{3}, 300 \mathrm{MHz}\right] \delta 1.00-1.20\left(\mathrm{~m}, 1 \mathrm{H}, \mathrm{CH}_{2}\right), 1.30-1.42\left(\mathrm{~m}, 2 \mathrm{H}, \mathrm{CH}_{2}\right), 1.43-1.54\left(\mathrm{~m}, 2 \mathrm{H}, \mathrm{CH}_{2}\right), 1.60-1.76\left(\mathrm{~m}, 1 \mathrm{H}, \mathrm{CH}_{2}\right)$, 2.80-3.00 (m, $\left.1 \mathrm{H}, \mathrm{CH}_{2}\right), 3.02-3.20\left(\mathrm{~m}, 4 \mathrm{H}, \mathrm{CH}_{2}\right), 3.20-3.40\left(\mathrm{~m}, 2 \mathrm{H}, \mathrm{CH}_{2}\right), 3.60-3.80\left(\mathrm{~m}, 1 \mathrm{H}, \mathrm{CH}_{2}\right), 4.96-5.30(\mathrm{~m}, 18 \mathrm{H}$, $\mathrm{CH}_{2} \mathrm{Ph}$ ), 6.70-6.96 (m, 5H, ArH), 7.20-7.60 (m, 42H, ArH), 7.70-8.10 (m, 4H, ArH). Anal. $\mathrm{C}_{91} \mathrm{H}_{85} \mathrm{~N}_{3} \mathrm{O}_{12}(\mathrm{C}, \mathrm{H}, \mathrm{N}, \mathrm{O})$.

Following the deprotection procedure, the OBn derivative $42(128.7 \mathrm{mg}, 0.09 \mathrm{mmol})$ gave a crude product which was then purified by triturating with diethyl ether to afford $23 \mathrm{mg}(42 \%)$ of 43 as a white solid; m.p. 185-187 ${ }^{\circ} \mathrm{C} .{ }^{1} \mathrm{H}-\mathrm{NMR}$ [CD $\left.{ }_{3} \mathrm{OD}, 300 \mathrm{MHz}\right] \delta 1.30-1.60\left(\mathrm{~m}, 4 \mathrm{H}, \mathrm{CH}_{2}\right), 1.70-1.80\left(\mathrm{~m}, 2 \mathrm{H}, \mathrm{CH}_{2}\right), 3.25-3.62\left(\mathrm{~m}, 8 \mathrm{H}, \mathrm{CH}_{2} \mathrm{NH}\right), 6.22-6.31(\mathrm{~m}, 3 \mathrm{H}$, $\mathrm{ArH}), 6.43(\mathrm{~d}, 1 \mathrm{H}, J=8.3 \mathrm{~Hz}, \mathrm{ArH}), 7.01(\mathrm{~d}, 2 \mathrm{H}, J=8.3 \mathrm{~Hz}, \mathrm{ArH}) .{ }^{13} \mathrm{C}-\mathrm{NMR}\left[\mathrm{CD}_{3} \mathrm{OD}, 75 \mathrm{MHz}\right] \delta 26.30\left(\mathrm{CH}_{2}\right), 28.10$ 
$\left(\mathrm{CH}_{2}\right), 36.03\left(\mathrm{CH}_{2}\right), 38.37\left(\mathrm{CH}_{2}\right), 48.20\left(\mathrm{CH}_{2}\right), 54.62\left(\mathrm{CH}_{2}\right), 106.39$ (ArC), 106.51 (ArC), 106.82 (ArC), $107.34(\mathrm{ArC})$, 107.47 (ArC), 115.67 (ArC), 117.55 (ArC), 117.60 (ArC), 117.64 (ArC), 132.54 (ArC), 132.56 (ArC), $132.94(\operatorname{ArC})$, 143.02 (ArC), 147.04 (ArC), 149.22 (ArC), 149.26 (ArC), 150.20 (ArC), 150.24 (ArC), $170.41(\mathrm{C}=\mathrm{O}), 170.43(\mathrm{C}=\mathrm{O})$, $171.81(\mathrm{C}=\mathrm{O})$. MS (ES+): m/z $602.2(\mathrm{M}+\mathrm{H})^{+}$. Anal. $\mathrm{C}_{28} \mathrm{H}_{31} \mathrm{~N}_{3} \mathrm{O}_{12}(\mathrm{C}, \mathrm{H}, \mathrm{N}, \mathrm{O})$.

Tris[2-(2',3',4'-trihydroxybenzamide)ethyl] amine (45)

According to the general procedure tris(2-aminoethyl)amine $(0.052 \mathrm{~mL}, 0.34 \mathrm{mmol})$ was treated with $2,3,4-$ tribenzyloxybenzoic acid $31(494 \mathrm{mg}, 1.12 \mathrm{mmol})$ to give $478 \mathrm{mg}(100 \%)$ of the OBn protected derivative 44 as a colourless oil. ${ }^{1} \mathrm{H}-\mathrm{NMR}\left(\mathrm{CDCl}_{3}, 300 \mathrm{MHz}\right) \delta 2.65\left(\mathrm{dd}, J=0.48 \mathrm{~Hz}, J=9.31 \mathrm{~Hz}, 12 \mathrm{H}, \mathrm{CH}_{2} \mathrm{NH}\right), 5.03\left(\mathrm{~s}, 6 \mathrm{H}, \mathrm{CH}_{2} \mathrm{O}\right), 5.10$ (s, 12H, $\left.\mathrm{CH}_{2} \mathrm{O}\right), 7.36(\mathrm{~m}, 51 \mathrm{H}, \mathrm{ArH})$. MS (ES+): m/z $1413(\mathrm{M}+\mathrm{H})^{+}$. Anal. $\mathrm{C}_{\mathrm{x}} \mathrm{H}_{30} \mathrm{~N}_{4} \mathrm{O}_{12}(\mathrm{C}, \mathrm{H}, \mathrm{N}, \mathrm{O})$.

Following the deprotection procedure, the $\mathrm{OBn}$ derivative $44(220 \mathrm{mg}, 0.15 \mathrm{mmol})$ gave a crude product which was then purified by triturating with diethyl ether to afford $32 \mathrm{mg}$ (35\%) of $\mathbf{4 5}$ as a white solid. Characterization of this compound in the literature was incomplete [29c] and NMR was made in $\mathrm{D}_{2} \mathrm{O}$. Missing data (melting point) and NMR in methanol were now included; m.p. $154-156^{\circ} \mathrm{C} .{ }^{1} \mathrm{H}-\mathrm{NMR}\left(\mathrm{CD}_{3} \mathrm{OD}, 300 \mathrm{MHz}\right) \delta 2.83\left(\mathrm{t}, J=6.20 \mathrm{~Hz}, 6 \mathrm{H}, \mathrm{CH}_{2} \mathrm{NH}\right), 3.49(\mathrm{t}, J$ $\left.=6.12 \mathrm{~Hz}, 6 \mathrm{H}, \mathrm{CH}_{2} \mathrm{NH}\right), 6.26(\mathrm{~d}, J=8.80 \mathrm{~Hz}, 3 \mathrm{H}, \mathrm{ArH}), 7.03(\mathrm{~d}, J=8.81 \mathrm{~Hz}, 3 \mathrm{H}, \mathrm{ArH}) . \mathrm{MS}(\mathrm{ES}+): \mathrm{m} / \mathrm{z} 603(\mathrm{M}+\mathrm{H})^{+}$. Anal. $\mathrm{C}_{27} \mathrm{H}_{30} \mathrm{~N}_{4} \mathrm{O}_{12}(\mathrm{C}, \mathrm{H}, \mathrm{N}, \mathrm{O})$.

\section{General Method for the synthesis of alkyl amides 50-52 and 57-59}

Benzotriazol-1-yl-oxytripyrrolidinophosphonium hexafluorophosphate (pyBOP) (2.2 mmol) was added to a solution of 2,3-dimethoxybenzoic acid $46(2.2 \mathrm{mmol})$ or 2-benzyloxysalicylic acid $53(2.2 \mathrm{mmol})$ in dry dichloromethane $(20 \mathrm{~mL})$. After $5 \mathrm{~min}$, triethylamine (TEA) $(2 \mathrm{mmol})$ and the corresponding diamine $(1 \mathrm{mmol})$ were added. The mixture was stirred at room temperature overnight and then evaporated to dryness. The residue was dissolved in ethyl acetate $(30 \mathrm{~mL})$ and washed successively with saturated solutions of citric acid $(3 \times 20 \mathrm{~mL}), \mathrm{NaHCO}_{3}(3 \times 20 \mathrm{~mL})$ and $\mathrm{NaCl}(1 \times 20 \mathrm{~mL})$. The residue was concentrated and purified by preparative centrifugal circular thin-layer chromatography (CCTLC) using dichloromethane/methanol $(9: 1 \rightarrow 1: 1)$ as the eluent.

The protected OMe derivatives 47-49 were deprotected using boron tribromide as was previously described to afford the deprotected derivatives 50-52. Melting points and characterization of these compounds were consistent with those found in the literature [31]. In our case the following total yields were obtained: $\mathbf{5 0}(81 \%), \mathbf{5 1}(99 \%)$ and $\mathbf{5 2}(50 \%)$.

Deprotection of the benzyl groups of $\mathbf{5 4 - 5 6}$ by catalytic hydrogenation in the presence of $10 \% \mathrm{Pd} / \mathrm{C}$ as was previously described afforded the corresponding phenol deprotected derivatives 57 (74\%), 58 (99\%) and $\mathbf{5 9}(50 \%)$. Melting points and characterization of these compounds were consistent with those found in the literature [31a, 39].

\section{N,N'-4,7,10-Trioxa-1,13-tridecanebis(2,3,4-hydroxybenzamide) (61)}

Benzotriazol-1-yl-oxytripyrrolidinophosphonium hexafluorophosphate (pyBOP) (0.37 mmol) was added to a solution of 2,3,4-tribenzyloxybenzoic acid $31(163.7 \mathrm{mg}, 0.37 \mathrm{mmol})$ in dry dichloromethane $(5 \mathrm{~mL})$. After 5 min, triethylamine (TEA) (0.37 mmol) and 4,7,10-trioxa-1,13-tridecanediamine (35.24 mg, $0.16 \mathrm{mmol})$ were added. The mixture was stirred at room temperature overnight and then evaporated to dryness. The residue was dissolved in ethyl acetate $(20 \mathrm{~mL})$ and washed successively with saturated solutions of citric acid $(3 \times 20 \mathrm{~mL}), \mathrm{NaHCO}_{3}(3 \times 20 \mathrm{~mL})$ and $\mathrm{NaCl}(1 \mathrm{x} 20 \mathrm{~mL})$. The 
residue was concentrated and purified by preparative centrifugal circular thin-layer chromatography (CCTLC) using hexane/ethyl acetate $(1: 1)$ as eluent to give $96.5 \mathrm{mg}(57 \%)$ of the OBn protected derivative $\mathbf{6 0}$ as a colourless oil. ${ }^{1} \mathrm{H}-\mathrm{NMR}$ $\left[\mathrm{CDCl}_{3}, 300 \mathrm{MHz}\right] \delta 1.50-1.60\left(\mathrm{~m}, 4 \mathrm{H}, \mathrm{CH}_{2}\right), 3.35\left(\mathrm{q}, 4 \mathrm{H}, J=6.4 \mathrm{~Hz}, \mathrm{CH}_{2} \mathrm{O}\right), 3.35\left(\mathrm{t}, 4 \mathrm{H}, J=5.8 \mathrm{~Hz}, \mathrm{CH}_{2} \mathrm{NH}\right), 3.43-3.49$ (m, 4H, $\left.\mathrm{CH}_{2} \mathrm{O}\right), 3.51-3.56\left(\mathrm{~m}, 4 \mathrm{H}, \mathrm{CH}_{2} \mathrm{O}\right), 4.97$ (s, 4H, $\left.\mathrm{CH}_{2} \mathrm{Ph}\right), 5.02\left(\mathrm{~s}, 8 \mathrm{H}, \mathrm{CH}_{2} \mathrm{Ph}\right), 6.74(\mathrm{~d}, 2 \mathrm{H}, J=8.7 \mathrm{~Hz}, \mathrm{ArH}), 7.19-$ $7.38(\mathrm{~m}, 30 \mathrm{H}, \mathrm{ArH}), 7.77(\mathrm{~d}, 2 \mathrm{H}, J=8.7 \mathrm{~Hz}, \mathrm{ArH}), 7.92(\mathrm{t}, 2 \mathrm{H}, J=5.5 \mathrm{~Hz}, \mathrm{NH}) .{ }^{13} \mathrm{C}-\mathrm{NMR}\left[\mathrm{CDCl}_{3}, 75 \mathrm{MHz}\right] \delta 29.70$ $\left(\mathrm{CH}_{2}\right), 36.80\left(\mathrm{CH}_{2}\right), 69.12\left(\mathrm{CH}_{2}\right), 70.09\left(\mathrm{CH}_{2}\right), 70.28\left(\mathrm{CH}_{2}\right), 71.27\left(\mathrm{CH}_{2} \mathrm{Ph}\right), 76.10\left(\mathrm{CH}_{2} \mathrm{Ph}\right), 109.47(\mathrm{ArCH}), 119.82$ $(\mathrm{ArCH}), 128.00(\mathrm{ArCH}), 128.81(\mathrm{ArCH}), 129.03(\mathrm{ArCH}), 129.18(\mathrm{ArCH}), 136.64(\mathrm{ArC}), 137.60(\mathrm{ArC}), 141.34(\mathrm{ArC})$, 152.16 (ArC), 156.17 (ArC), $165.55(\mathrm{C}=\mathrm{O})$. Anal. $\mathrm{C}_{66} \mathrm{H}_{68} \mathrm{~N}_{2} \mathrm{O}_{11}(\mathrm{C}, \mathrm{H}, \mathrm{N}, \mathrm{O})$.

Following the deprotection procedure, the OBn derivative $\mathbf{6 0}(89.6 \mathrm{mg}, 0.084 \mathrm{mmol})$ gave a crude product which was coevaporated with diethyl ether to give $40 \mathrm{mg}(73 \%)$ of $\mathbf{6 1}$ as a brownish oil. ${ }^{1} \mathrm{H}-\mathrm{NMR}$ [CD $\left.\mathrm{CD}_{3} \mathrm{OD}, 300 \mathrm{MHz}\right] \delta 1.74$ (q, $\left.4 \mathrm{H}, J=6.4 \mathrm{~Hz}, \mathrm{CH}_{2}\right), 3.17-3.61\left(\mathrm{~m}, 16 \mathrm{H}, \mathrm{CH}_{2} \mathrm{O}, \mathrm{CH}_{2} \mathrm{NH}\right), 6.25(\mathrm{~d}, 2 \mathrm{H}, J=8.8 \mathrm{~Hz}, \mathrm{ArH}), 7.00(\mathrm{~d}, 2 \mathrm{H}, J=8.8 \mathrm{~Hz}, \mathrm{ArH})$. ${ }^{13} \mathrm{C}-\mathrm{NMR}\left[\mathrm{CD}_{3} \mathrm{OD}, 75 \mathrm{MHz}\right] \delta 30.61\left(\mathrm{CH}_{2}\right), 38.25\left(\mathrm{CH}_{2}\right), 70.72\left(\mathrm{CH}_{2}\right), 71.41\left(\mathrm{CH}_{2}\right), 71.66\left(\mathrm{CH}_{2}\right), 108.25(\mathrm{ArC}), 109.95$ $(\mathrm{ArCH}), 119.47(\mathrm{ArCH}), 134.03(\mathrm{ArC}), 150.96(\mathrm{ArC}), 151.93(\mathrm{ArC}), 172.06(\mathrm{C}=\mathrm{O}) . \mathrm{MS}(\mathrm{ES}+)$ : m/z $525.5(\mathrm{M}+\mathrm{H})^{+}$. Anal. $\mathrm{C}_{24} \mathrm{H}_{32} \mathrm{~N}_{2} \mathrm{O}_{11}(\mathrm{C}, \mathrm{H}, \mathrm{N}, \mathrm{O})$.

\section{N,N'-Dodecamethylenbis(2,3,4-trimethoxybenzamide) (63)}

In a procedure analogous to that described for compound $\mathbf{6 0}$, benzotriazol-1-yl-oxytripyrrolidinophosphonium hexafluorophosphate (pyBOP) $(0.5 \mathrm{mmol})$ and 2,3,4-trimethoxybenzoic acid $\mathbf{6 2}(106.1 \mathrm{mg}, 0.5 \mathrm{mmol})$ in dry dichloromethane $(5 \mathrm{~mL})$ was treated with triethylamine (TEA) $(0.5 \mathrm{mmol})$ and 1,12-dodecamethylendiamine $(34.46 \mathrm{mg}$, $0.20 \mathrm{mmol})$ to obtain $85.2 \mathrm{mg}(72 \%)$ of 63 as a white solid; m.p. $62-64{ }^{\circ} \mathrm{C} .{ }^{1} \mathrm{H}-\mathrm{NMR}\left[\mathrm{CDCl}_{3}, 300 \mathrm{MHz}\right] \delta 1.18-1.41(\mathrm{~m}$, 16H, $\left.\mathrm{CH}_{2}\right), 1.50-1.62\left(\mathrm{~m}, 4 \mathrm{H}, \mathrm{CH}_{2}\right), 3.40\left(\mathrm{q}, 4 \mathrm{H}, J=6.6 \mathrm{~Hz}, \mathrm{CH}_{2} \mathrm{NH}\right), 3.82\left(\mathrm{~s}, 6 \mathrm{H}, \mathrm{CH}_{3}\right), 3.85\left(\mathrm{~s}, 6 \mathrm{H}, \mathrm{CH}_{3}\right), 3.91(\mathrm{~s}, 6 \mathrm{H}$, $\left.\mathrm{CH}_{3}\right), 6.72(\mathrm{~d}, 2 \mathrm{H}, J=9.5 \mathrm{~Hz}, \mathrm{ArH}), 7.84(\mathrm{~d}, 2 \mathrm{H}, J=9.5 \mathrm{~Hz}, \mathrm{ArH}), 7.87-7.93(\mathrm{~m}, 2 \mathrm{H}, \mathrm{NH}) .{ }^{13} \mathrm{C}-\mathrm{NMR}\left[\mathrm{CDCl}_{3}, 75 \mathrm{MHz}\right] \delta$ $27.31\left(\mathrm{CH}_{2}\right), 29.52\left(\mathrm{CH}_{2}\right), 29.75\left(\mathrm{CH}_{2}\right), 29.83\left(\mathrm{CH}_{2}\right), 39.79\left(\mathrm{CH}_{2}\right), 56.21\left(\mathrm{CH}_{3}\right), 61.13\left(\mathrm{CH}_{3}\right), 107.73(\operatorname{ArC}), 119.35(\mathrm{ArC})$, 126.79 (ArC), 141.88 (ArC), 152.48 (ArC), 156.40 (ArC), 164.97 (C=O). Anal. $\mathrm{C}_{50} \mathrm{H}_{84} \mathrm{~N}_{2} \mathrm{O}_{8}(\mathrm{C}, \mathrm{H}, \mathrm{N}, \mathrm{O})$.

\section{Supporting information}

General chemistry and biological procedures as well as copies of representative ${ }^{1} \mathrm{H}$ and ${ }^{13} \mathrm{CNMR}$ spectra are included.

\section{Acknowledgments}

Financial support of KU Leuven (GOA 10/14; PF 10/18) and the FWO (G-0528.12N) was provided for the antiviral experiments. The Spanish MEC/ MICINN/MINECO (Projects: SAF 2009-13914-C02-01; SAF 2012-39760-C02-01; Plan Nacional de Cooperación Público-Privada. Subprograma INNPACTO IPT-2012-0213-060000) and the Comunidad de Madrid (BIPEDD2-CM-S2010/BMD-2457) are also acknowledged for financial support. The Spanish MEC/MINECCO are also acknowledged for a grant to E. Rivero-Buceta. We thank Leentje Persoons, Frieda De Meyer, Leen Ingels and Stijn Delmotte, Katrien Geerts, Sam Noppen and Inge Vliegen for excellent technical assistance 


\section{References}

[1] I. Saito, T. Miyamura, A. Obayashi, H. Harada, T. Katayama, S. Kikuchi, Y. Watanabe, S. Koi, M. Onji, Y. Ohata, QL. Choo, M. Houghton, G. Kuo, Hepatitis C virus infection is associated with the development of hepatocellular carcinoma, Proc. Natl. Acad. Sci. USA 87 (1990) 6547-6549.

[2] (a) Fried MW, Shiffman ML, Reddy KR et al. Peginterferon alfa-2a plus ribavirin for chronic hepatitis $C$ virus infection. N. Engl. J.Med. 347 (2002) 975-82. (b) M.G. Ghany, D.R. Nelson, D.B. Strader, D.L. Thomas, L.B. Seeff, An update on treatment of genotype 1 chronic hepatitis $\mathrm{C}$ virus infection: 2011 practice guideline by the American Association for the Study of Liver Diseases. Hepatology (Baltimore, Md.) 54 (2011) 1433-1444. (c) EASL Clinical Practice Guidelines, Management of hepatitis C virus infection. J. Hepatol. 55 (2011) 245-264.

[3] (a) T.J. Liang, M.G. Ghany, Current and future therapies for hepatitis C virus infection. N. Engl. J. Med. 368 (2013) 1907-1917. (b) P.J. Pockros, Drugs in development for chronic hepatitis C: a promising future. Expert Opin. Biol. Ther. 11 (2011) 1611-22. (c) C. Sarrazin, C. Hezode, S. Zeuzem, J.M. Pawlotsky, Antiviral strategies in hepatitis C virus infection. J. Hepatol. 56 (Suppl. 1) (2012) S88-100. (d) C.A.M. Stedman, Current prospects for interferon-free treatment of hepatitis C in 2012. J. Gastroenterol. Hepatol. 28 (1) (2013) 38-45.

[4] (a) I.M. Jacobson, J.G. McHutchison, G. Dusheik et al. , Telaprevir for previously untreated chronic hepatitis C virus infection. N. Engl. J. Med. 364 (2011) 2405-2416. (b) F. Poordad, J. McCone Jr., B. R. Bacon et al., Boceprevir for untreated chronic HCV genotype 1 infection. N. Engl. J. Med. 364 (2011) 1195-1206. (c) C. Scheridan, New Merck and Vertex drugs raise standard of care in hepatitis C. Nature Biotechnol. 29 (2011) 553-554. (d) J.G. McHutchison,G.T. Everson, S.C. Gordon et al., Telaprevir with peginterferon and ribavirin for chronic HCV genotype 1 infection. N. Engl. J.Med. 360 (2009), 1827-1838. (e) C. Hezode, N. Forestier, G. Dusheiko, G., et al., Telaprevir and peginterferon with or without ribavirin for chronic HCV infection. N. Engl. J. Med. 360 (2009) 18391850. (e)B.R. Bacon, S.C. Gordon, E. Lawitz, et al., 2011. Boceprevir for previously treated chronic HCV genotype 1 infection. N. Engl. J. Med. 364, 1207-1217.

[5] (a) J.M. Pawlotsky. Treatment failure and resistance with direct-acting antiviral drugs against hepatitis $\mathrm{C}$ virus. Hepatology 53, (2011) 1742-51. (b) S. Susser, C. Welsch, Y. Wang, M. Zettler, F.S.Domingues, U. Karey, E. Hughes, R. Ralston, X. Tong, E. Herrmann, S. Zeuzem, C. Sarrazin, Characterization of resistance to the protease inhibitor boceprevir in hepatitis C virus-infected patients. Hepatology 50 (2009) 1709-18.

[6] (a) R.J. Pomerantz, D.L. Horn, Twenty years of therapy for HIV-1 infection. Nat. Med. 9 (7), (2003) 867-73. (b) P.A.Volberding, S.G. Deeks, Antiretroviral therapy and management of HIV infection. Lancet, 376 (9734) (2010) 4962. (c) C. Flexner, HIV drug development: the next 25 years. Nat. Rev. Drug. Discov., 6 (2007) 959-66.

[7] (a) D. Ferreira, J. P. Steynberg, J. P. Roux, E. V. Brandt, Diversity of structure and function in oligomeric flavanoids.Tetrahedron 48 (1992) 1743-1803. (b) D. Ferreira, R. Bekker, Oligomeric proanthocyanidins: naturally occurring O-heterocycles. Nat. Prod. Rep. 13 (1996) 411-433. (c) J.G. Handique, J.B. Baruah, Polyphenolic compounds: an overview. React. Funct. Polym. 52 (2002) 163-188. (d) J. Harborne, Plant polyphenols. in: Bell E., Charlwood, B. (Eds.), Encyclopedia of Plant Physiology, Springer Verlag, Berlin Heidelberg New York, 1980, pp. 329-395. (e) E. Haslam, Y. Cai, Plant polyphenols (vegetable tannins): gallic acid metabolism. Nat. Prod. Rep. 11 (1994) 41-65. (f) E. Haslam, Practical Polyphenolics-From Structure to Molecular Recognition and Physiological 
Action; Cambridge University Press: Cambridge, 1998 (g) R. W. Hemingway, P. E., Laks, Eds. Plant Polyphenols. Synthesis, Properties, Significance; Plenum: New York, London, 1992 (h) S., Quideau, K. S. Feldman, Ellagitannin Chemistry. Chem. Rev. 96 (1996) 475-503. (i) S. Quideau, D. Deleux, C. Douat-Casassus, L. Pousegu, Plant polyphenols: chemical properties, biological activities, and synthesis. Chem. Int. Ed. 50 (2011) 586-621. (j) E. Haslam, J. Nat. prod. 59 (1996) 205-215. (k) P. Sarni-Manchado, J-M Canals-Bosh, G. Mazerolles, V, Cheynier, J. Agric. Food. Chem. 56 (2008) 9563-9569.

[8] (a) A. Ali, F. Alqurainy, (Eds) Activities of Antioxidants in Plants under Environmental Stress, Transworld Research Network, 2006. (b) M.M. Caldwell, R. Robberecht, S.D. Flint, Internal filters: Prospects for UV-acclimation in higher plants. Physiol. Plant 58 (1983) 445-450. (c) H. A. Stafford, K. Ibrahim, Eds. Phenolic Metabolism in Plants; Plenum: New York, 1992.

[9] I. Mueller-Harvey, Unravelling the conundrum of tannins in animal nutrition and health. .J. Sci. Food. Agric. 86 (1992) 2010-2037.

[10] (a) I.E. Dreosti, Bioactive ingredients: antioxidants and polyphenols in tea. Nutr. Rev. 54 (1996) S51-S58. (b) N. Khan, H. Mukhtar, Tea polyphenols for health promotion. Life Sci. 81 (2007) 519-533. (c) N. Taylor, Green Tea, the Natural Secret for a Healthier Life: Kensington Publishing Corp: New York, N.Y., 2007 (d) H. Wang, G.J. Provan, K. Helliwell, Tea flavonoids, their functions, utilization and analysis. Trends Food Sci. Tech. 11 (2000) 152-160.

[11] (a) J.V. Higdon, B. Frei, Tea catechins and polyphenols: health effects, metabolism and antioxidant functions. Crit Rev. Food Sci. Nutr. 43 (1) (2003) 89-143. (b) S.V. Jovanovic, S. Steenken, M. Tosic, B. Marjanovic, M.G. Simic, Flavonoids as antioxidants. J. Am. Chem. Soc. 116 (1994) 4846-4851. (c) C. Cabrera, R. Artacho, R. Giménez, Beneficial effects of green tea-a review. J Am Coll Nutr. 2 (2006) 79-99. (d) Urquiaga, I., Leighton, F. Plant Polyphenol Antioxidants and Oxidative Stress. Biol. Res. 33 (2000) 55-64.

[12] (a) R. Cooper, D.J. Morré., D.M. Morré, Medicinal benefits of green tea: part II. Review of anticancer properties. J. Alternat. Complement. Med. 11 (2005) 639-652. (b) N. Khan, H. Mukhtar, Multitargeted therapy of cancer by green tea polyphenols. Cancer Lett., 269 (2) (2008) 269-80. (c) S.N. Nichenametla, T.G. Taruscio, D.L. Barney, J.H. Exon, A review of the effects and mechanisms of polyphenolics in cancer. Crit Rev Food Sci Nutr., 46(2) (2006) 161-83. (d) S. Shankar, S. Ganapathy, R.K. Srivastava, Green tea polyphenols: biology and therapeutic implications in cancer. Front Biosci. 12 (2007) 4881-4899. (e) C.S.Yang, X. Wang, G., Lu, S.C. Picinich, Regulation of innate immune responses in the brain. Nat. Rev. Cancer 9 (2009) 429-439. (f) C.S Yang, H. Wang, Mechanistic issues concerning cancer prevention by tea catechins. Mol Nutr Food Res. 55 (6) (2011) 819-31. (g) N.T. Zaveri, Green tea and its polyphenolic catechins: medicinal uses in cancer and noncancer applications. Life Sci. 78 (18) (2006) 2073-2080.

[13] (a) A. Basu, E.A. Lucas, Mechanisms and effects of green tea on cardiovascular health. Nutr Rev. (8 Pt 1): (2007) 361-75. (b) P.V. Babu, D. Liu, Green tea catechins and cardiovascular health: an update, Curr Med Chem. 15(18) (2008) 1840-50. (c) A. Deka, J.A. Vita, Tea and cardiovascular disease. Pharmacol Res, 64(2): (2011) 136-45. (d) Islam, M.A. Cardiovascular effects of green tea catechins: progress and promise. Recent Pat Cardiovasc Drug Discov. 7(2) (2012) (2012) 88-99. (e) N. Jochmann, G. Baumann, V. Stangl, Green tea and cardiovascular disease: from molecular targets towards human health. Curr Opin Clin Nutr Metab Care. 11(6) (2008) 758-65. (f) A.B. Pon Velayutham, D. Liu, Green Tea Catechins and Cardiovascular Health: An Update. Curr. Med. Chem., 15 (18) (2008) 
1840-1850. (g) Wolfram, S. Effects of green tea and EGCG on cardiovascular and metabolic health. J. Am. Coll. Nutr. (2007) 26 (4), 373S-388S.

[14] (a) S. Mandel, M.B. Youdim, Catechin polyphenols: neurodegeneration and neuroprotection in neurodegenerative diseases. Free Radic Biol Med., 37(3) (2004) 304-17. (b) S.A. Mandel, T., Amit, O. Weinreb, M.B. Youdim, Understanding the broad-spectrum neuroprotective action profile of green tea polyphenols in aging and neurodegenerative diseases. J Alzheimers Dis. 25(2) (2011) 187-208. (c) T. Pan, J. Jankovic, W. Le, Potential therapeutic properties of green tea polyphenols in Parkinson's disease. Drugs Aging, 20(10) (2003) 711-21.

[15] (a) M. Daglia, Polyphenols as antimicrobial agents. Current Opinion in Biotechnology, 23 (2012) 174-181. (b) Friedman, M. Overview of antibacterial, antitoxin, antiviral and antifungal activities of tea flavonoids and teas. Mol. Nutr. Food Res., 51 (2007) 116-134. (c) J.M. Hamilton-Miller, Antimicrobial properties of tea (Camellia sinensis L.). Antimicrob. Agents Chemother. 39 (1995) 2375-2377. (d) E. Haslam, Natural polyphenols (vegetable tannins) as drugs: possible modes of action. J. Nat. Prod. 59 (1996) 205-215. (e) P.W. Taylor, J.M.T. Hamilton-Miller, P.D. Stapleton, Antimicrobial properties of green tea catechins. Food Sci. Technol. Bull., 2 (2005) 71-81. (f) Yam, T.S.; Shat, S.; Hamilton-Miller, J.M. Microbiological activity of whole and fractionated crude extracts of tea (Camellia sinensis), and of tea components. FEMS Microbiol. Lett, 152 (1) (1997) 169-174.

[16] T.P., Tim, A. Cushnie, J. Lamb, Recent advances in understanding the antibacterial properties of flavonoids. Int. J. Antimicrob. Agents 38 (2) (2011) 99-107.

[17] M. Hirasawa, K. Takada, Multiple effects of green tea catechin on the antifungal activity of antimycotics against Candida albicans 53(2) (2004) 225-229.

[18] (a) L-K-, Chang, T.T. Wei, Y.F. Chiu, C.P. Tung, J.Y. Chuang, S.K. Hung, C. Li, S.T. Liu, Inhibition of Epstein-Barr virus lytic cycle by (-)-epigallocatechin gallate. Biochem Biophys. Res. Commun., 301 (2003) 1062-1068. (b) G. Fassina, A. Buffa, R. Benelli, O.E.Varnier, D.M. Noonan, A. Albini, Polyphenolic antioxidant (-)-epigallocatechin-3gallate from green tea as a candidate anti-HIV agent. AIDS, 16 (2002) 939-941. (c) A., Hamza, C.G. Zhan, How can (-)epigallocatechin gallate from green tea prevent HIV-1 infection?. J. Phys. Chem. B, 110 (2006) 2910-2917. (d) H.Y. Ho, M.L. Cheng, S.F. Weng, Y.L. Leu, D.T. Chin. Antiviral effect of epigallocatechin gallate on enterovirus 71. J. Agric. Food Chem, 52 (2009) 6140-6147. (e) C.E. Isaacs, W. Xu, G. Merz, S. Hillier, I. Roham, G.Y, Wen, Digallate dimers of (-)-Epigallocatechin gallate inactivate herpes simplex virus. Antimicrob. Agents Chemother., 55 (2011) 5646-5653. (f) F. Jiang, W. Chen, K.Yi, Z.Wu, Y. Si, W. Han, Y. Zhao, The evaluation of catechins that contain a galloyl moiety as potential HIV-1 integrase inhibitors. Clin. Immunol, 137 (2010) 347-356. (g) K. Kawai, N.H. Tsuno, J. Kitayama, Y. Okaji, K. Yazawa, M., Asakage, N. Hori, T. Watanabe, K.Takahashi, H. Nagawa, Epigallocatechin gallate, the main component of tea polyphenol, binds to CD4 and interferes with gp120 binding, J. Allergy Clin. Immunol, 112 (2003) 951-957. (h) J., Li, L. Zhou, Y. Zhang, Studies on the effects of tea catechins against hepatitis B virus infection. Zhonghua Yu Fang Yi Xue Za Zhi 35, (2001) 404-407. (i) Y-T. Lin, Y-H. Wu, CK. Tseng, C-K. Lin, W-C. Chen, Y-C. Hsu, J-C. Lee, Green tea phenolic epicatechins inhibit hepatitis C virus replication via cyclooxygenase-2 and attenuate virus-induced inflammation. Plos One, 8 (2013) 1-10. (j) S. Liu, H. Lu, Q. Zhao, Y. He, J. Niu, A.K. Debhath, S. Wu, S. Jiang, Theaflavin derivatives in black tea and catechin derivatives in green tea inhibit HIV-1 entry by targeting gp41. Biochim. Biophys Acta, 1723 (2005) 270-281. (k) C.L. 
Nance, E.B. Siwak, W.T. Shearer, Preclinical development of the green tea catechin, epigallocatechin gallate, as an HIV-1 therapy. J. Allergy. Clin. Immunol., 123 (2009) 459-465. (1) M. Nakayama, K. Suzuki, M. Toda, S. Okubo, Y. Hara, T. Shimamura, Preclinical development of the green tea catechin, epigallocatechin gallate, as an HIV-1 therapy. Antivir. Res., 21 (1993) 289-299. (m) J-M. Song, K-H. Lee, B-L. Seong, Antiviral effect of catechins in green tea on influenza virus. Antiviral Res. 68 (2) (2005) 66-74. (n) J.M.Weber, A. Ruzindana-Umunyana, I. Imbeault, S. Sircar, Inhibition of adenovirus infection and adenain by green tea catechins. Antiviral Res. 58 (2), (2003) 168-173. (o) M. P., Williamson, T. G. McCormick, C. L. Nance, W. T. Shearer, Epigallocatechin gallate, the main polyphenol in green tea, binds to the T-cell receptor, CD4: Potential for HIV-1 therapy. J. Allergy Clin. Immunol. 118 (6) (2006) 1369-1374. (p) K.Yamaguchi, M. Honda, H. Ikigai, Y. Hara, T. Shimamura, Inhibitory effects of (-)-epigallocatechin gallate on the life cycle of human immunodeficiency virus type 1 (HIV-1). Antiviral Res., 53 (1) (2002) 19-34. (q) Ch. E. Isaacs, G.Y. Wen, X. Weimin, J.H. Jia, L. Rohan, Ch. Corbo, V. Di Maggio, E. C., Jr. Jenkins, S. Hillier, Epigallocatechin gallate inactivates clinical isolates of Herpes Simplex Virus. Antimicrob Agents Chemother. 52(3) (2002) 962-970. (r) Y. Zhao, F. Jiang, P. Liu, W. Chen, K. Yi, Catechins containing a galloyl moiety as potential antiHIV-1 compounds. Drug Discovery Today, 17 (11-12) (2012) 630-635.

[19] M.M. Silva, M.R. Santos, G. Caroco, R. Rocha, G. Justino, L. Mira, Structure-antioxidant Activity Relationships of Flavonoids: A Re-examination. Free Radical Res., 36 (11) (2002) 1219-1227.

[20] T. Taguri, T. Tanaka, I. Kouno, Antibacterial Spectrum of Plant Polyphenols and Extracts Depending upon Hydroxyphenyl Structure. Biol. Pharm. Bull, 29 (11) (2006) 2226-2235.

[21] (a) I. Kubo, N. Masuoka, P. Xiao, H. Haraguchi, Antioxidant activity of dodecyl gallate. J. Agric. Food. Chem, 50 (2002) 3533-3539. (b) C.A. Van der Heijden, P.J. Janssen, J.J. Strik, Toxicology of gallates: A review and evaluation. Food Chem Toxicol., 24 (10-11) (1986) 1067-1070.

[22] (a) K. Dodo, T. Minato, T. Noguchi-Yachide, M. Suganuma, Y. Hashimoto, Antiproliferative and apoptosis-inducing activities of alkyl gallate and gallamide derivatives related to (- )-epigallocatechin gallate. Bioorg. Med. Chem., 16 (2008) 7975-7982. (b) K., Dodo, T. Minato, Y. Hashimoto, Structure-Activity Relationship of Bis-Galloyl Derivatives Related to (-)-Epigallocatechin Gallate. Chem. Pharm. Bull, 57 (2), (2009) 190-194. (c) S. M. Fiuza, C. Gomes, L. J. Teixeira, M. T. Girão da Cruz, M. N. D. S. Cordeiro, N. Milhazes, F. Borges, M. P. M. Marques, Phenolic acid derivatives with potential anticancer properties-a structure-activity relationship study. Part 1: Methyl, propyl and octyl esters of caffeic and gallic acids. Bioorg. Med. Chem. 12 (2004) 3581-3589. (d) C. Frey, M. Pavani, G. Cordano, S. Muñoz, E. Rivera, J. Medina, A. Morello, J. Diego Maya, J. Ferreira, Comparative cytotoxicity of alkyl gallates on mouse tumor cell lines and isolated rat hepatocytes. Comp. Biochem. Physiol. A Mol. Integr. Physiol. 146 (4) (2006) 520-527. (e) R.Veluri, R.P. Singh, Z. Liu, J.A. Thompson, R. Agarwal, C. Agarwal, Fractionation of grape seed extract and identification of gallic acid as one of the major active constituents causing growth inhibition and apoptotic death of DU145 human prostate carcinoma cells. Carcinogenesis, 27 (7) (2006) 1445-1453.

[23] (a) I. Kubo, K., Fujita, K. Nihei, Anti-Salmonella activity of alkyl gallates. J. Agric. Food. Chem, 50 (2002) $6692-$ 6696. (b) I., Kubo, P. Xiao, K. Fujita, Anti-MRSA activity of alkyl gallates. Bioorg. Med. Chem. Lett., 12 (2002) 
113-116. (c) I. Kubo, K. Fujita, K. Nihei, N. Masuoka, Non-antibiotic antibacterial activity of dodecyl gallate. Bioorg. Med. Chem., 11 (2003) 573-580. (d) I. Kubo, K. Fujita, K. Nihei, A. Nihei, Antibacterial activity of alkyl gallates against Bacillus subtilis. J. Agric. Food. Chem, 52 (2004) 1072-1076. (e) P.D. Stapleton, S. Shah, J.C. Anderson, Y. Hara, J.M. Hamilton-Miller, P.W. Taylor, Modulation of $\beta$-lactam resistance in Staphylococcus aureus by catechins and gallates. Int. J. Antimicrob Agents, 23 (5) (2004) 462-467.

[24] K. Fujita, I. Kubo, Antifungal activity of octyl gallate. Int. J. Food Microbiol., 79 (2002) 193-201.

[25] (a) C.J. Kane, J.H. Menna, C-C. Sung, Y-Ch. Yeh, Methyl Gallate, Methyl-3,4,5-trihydoxy-benzoate, is a potent and highly specific inhibitor of herpes simplex virus in vitro. II. Antiviral activity of methyl gallate and its derivatives. Biosci. Rep., 8 (1988) 95-102. (b) J. M. Kratz, C. R. Andrighetti-Fröhner, P. C. Leal, R. J. Nunes, R. A. Yunes, E. Trybala, T. Bergström, C. R. M. Barardi, C.M.O. Simões, Evaluation of Anti-HSV-2 Activity of Gallic Acid and Pentyl Gallate. Biol. Pharma. Bull. 31 (5) (2008) 903-907. (c) J. M. Kratz, C. R. Andrighetti-Fröhner, D. J. Kolling, P. C. Leal, C. C. Cirne-Santos, R. A. Yunes, R. J. Nunes, E. Trybala, T. Bergström, I.C.P.P. Frugulhetti, C. R. M. Barardi, C. M. O. Simões, Anti-HSV-1 and anti-HIV-1 activity of gallic acid and pentyl gallate. Mem Inst Oswaldo Cruz, Rio de Janeiro, Vol. 103 (5), (2008) 437-442. (d) L.A. Savi, P.C. Leal, T.O. Vieira, R. Rosso, R.J. Nunes, R.A. Yunes, T.B. Creczynski-Pasa, C.R. Barardi, C.M.O. Simões, Evaluation of anti-herpetic and antioxidant activities, and cytotoxic and genotoxic effects of synthetic alkyl-esters of gallic acid. Arzneim.-Forsch./Drug. Res., 55: (2005) 66-75. (e) H. Yamasaki, M. Uozaki, Y. Katsuyama, H. Utsynomiya, T. Arakawa, M. Higuchi, T. Higuti, A. Koyama, H. Antiviral effect of octyl gallate against influenza and other RNA viruses. Int. J. Mol. Med., 19 (2007) 685-688.

[26] L. Nianguang, T. Yuping, D. Jinao CN101585769 (A)-2009-11-25.

[27] S. Benedikt, B. Coppens, J.Van Hemel, WO0130299-(A2)-2001-05-03.

[28] D. Lamoral-Theys, L. Pottier, F. Kerff, F. Dufrasne, F. Proutiere, N. Wauthoz, P. Neven, L. Ingrassia, P. Van Antwerpen, F. Lefranc, M-. Gelbcke, B. Pirotte, J-L. Kraus, J. Nève, A. Kornienko, R. Kiss, J. Dubois, Simple di- and trivanillated exhibit cytostatic properties toward cancer cells resistant to pro-apoptotic stimuli. Bioorganic \& Medicinal Chemistry, 18 (11) (2010) 3823-3833.

[29] (a) K.J. Bell, A. N. Westra, R. J. Warr, J. Chartres, R. Ellis, Ch. C. Tong, A. J. Blake, P.A. Tasker, M. Schröder, Outer-sphere coordination chemistry: selective extraction and transport of the $\left[\mathrm{PtCl}_{6}\right]^{2-}$ anion. Angew. Chem. Int. Ed., 47 (2008) 1745-1748. (b) F. Belin, P. Barthélémy, K.Ruiz, J.M. Lacombe, B. Pucci Synthetic gallic acid derivatives as models for a comprehensive study of antioxidant activity. Helv. Chim. Acta, 86 (2) (2003) 247-265. (c) A.R. Bulls A.R., C. G. F.E. Pippin, K. N. Hahn Raymond Synthesis and characterization of a series of Vanadium-Tunichrome B1 analogues. Crystal structure of a tris(catecholamine) complex of vanadium. J. Am. Chem. Soc. 112, (1990) 26272632. (d) R.J. Warr, A. N. Westra, K. J. Bell, J. Chartres, R. Ellis, C. Tong, T.G. Simmance, A. Gadzhieva, A.J. Blake, P.A. Tasker, M. Schröder, Selective extraction and transport of the $\left[\mathrm{PtCl}_{6}\right]^{2-}$ anion through outer-sphere coordination chemistry. Chem. Eur. J., 15 (19) (2009) 4836-4850.

[30] N.Takashi, K. Kumiko, A. Akiko, M. Kenji, T. Koichiro, JP8143525 (A), 1996-06-04.

[31] (a) K. K. Bhargava, R.W. Grady, A. Cerami, New compounds: $N{ }^{-}{ }^{1}, N^{8}$-bis(2, 3-dihydroxybenzoyl)spermidine and analogs as potential iron-chelating drugs. J. Pharm. Sci, 69 (8) (1980) 986-989. (b) E.J. Enemark, T.D.P, Stack. Spectral and structural characterization of two ferric coordination modes of a simple bis(catecholamide) ligand: Metal-assisted self-assembly in a siderophore analog. Inorg. Chem, 35 (10) (1996) 2719-2720. (c) L. Souleré, C. 
Viodé, J. Périé, P. Hoffmann Selective Inhibition of Fe- versus Cu/Zn-Superoxide Dismutases by 2,3Dihydroxybenzoic Acid Derivatives. Chem. Pharm. Bull. 50 (5) (2002) 578-582. (d) F. L. Weitl, K. N. Raymond Specific sequestering agents for the actinides. 3. Polycatecholate ligands derived from 2,3-dihydroxy-5-sulfobenzoyl conjugates of diaza- and tetraazaalkanes. J. Am. Chem. Soc., 102 (1980) 2289-2293. (e) K.J. Winstanley, D.K. Smith, Ortho-Substituted Catechol Derivatives: the effect of intramolecular hydrogen-bonding pathways on chloride anion recognition. J.Org. Chem, 72 (8) (2007) 2803-2815.

[32] J. Paeshuyse, I. Vliegen, L. Coelmont, P. Leyssen, O. Tabarrini, P. Herdewijn, H. Mittendorfer, J. Easmon, V. Cecchetti, R. Bartenschlager, G. Puerstinger, J. Neyts, Comparative in vitro anti-hepatitis C virus activities of a selected series of polymerase, protease, and helicase inhibitors. Antimicrob Agents Chemother. 52(9) (2008) 34333437.

[33] M. P. Windisch, M. Frese, A. Kaul, M. Trippler, V. Lohmann, R. Bartenschlager. Dissecting the interferon-induced inhibition of hepatitis C virus replication by using a novel host cell line. J.Virol. 79 (2005) 13778-13793.

[34] L.J. Stuyver, T.R. McBrayer, P.M. Tharnish, A.E. Hassan, C.K. Chu, K.W. Pankiewicz, K.A. Watanabe, R.F. Schinazi, M.J. Otto, Dynamics of subgenomic hepatitis C virus replicon RNA levels in Huh-7 cells after exposure to nucleoside antimetabolites. J Virol. 77(19) (2003) 10689-94.

[35] M.F. Bassendine, D.A. Sheridan, D.J. Felmlee, S.H. Bridge, G.L. Toms, R.D. Neely, HCV and the hepatic lipid pathway as a potential treatment target. J. Hepatol., 55(6) (2011) 1428-40.

[36] A.L. Rasmussen, D.L. Diamond, J.E. McDermott, X. Gao, T.O. Metz, M.M. Matzke, V.S. Carter, S.E. Belisle, M.J. Korth, K.M. Waters, R.D. Smith, M.G. Katze, Systems virology identifies a mitochondrial fatty acid oxidation enzyme, dodecenoyl coenzyme A delta isomerase, required for hepatitis $\mathrm{C}$ virus replication and likely pathogenesis. J Virol. 2011, 85(22) (2011) 11646-54.

[37] M.T. Donato, M.J. Gómez-Lechón, Drug-induced liver steatosis and phospholipidosis: cell-based assays for early screening of drug candidates. Curr Drug Metab. 2012, 13(8) (2012) 1160-73.

[38] S.E. Brevitt, E.W. Tan, Synthesis and in vitro evaluation of two progressive series of bifunctional polyhydroxybenzamide catechol-O-methyltransferase inhibitors. J. Med. Chem. 41 (1997) 2035-2039.

[39] (a) D. J. Brennan, A.P. Haag, J. E. White, C.N. Brown, High-Barrier Poly(hydroxy amide ethers): Effect of Polymer Structure on Oxygen Transmission Rates. Macromolecules, 31 (8) (1998) 2622-2630. (b) G. Daidone, D. Raffa, B. Maggio, S. Plescia, M. Matera, A. Caruso, Synthesis and evaluation of the analgesic and antiinflammatory activities of N, N' bis 2 hydroxybenzoyldiaminoalkanes. Il farmaco, 45 (1990) 285-292. 